\title{
A Preliminary Up-To-Date Review on Pakistani Medicinal Plants with Potential Antioxidant Activity
}

\author{
Adil Hussain \\ Department of Biotechnology, Faculty of Life Sciences, University of Okara, Okara 56130 Pakistan
}

\section{ABSTRACT}

Background: There exist natural antioxidants in plants that scavenge harmful free radicals from the body. Free radicals are species of chemical origin with an unpaired electron and play a pivotal role in combating health-related problems like lung damage, inflammation, and cardiovascular ailments etc. Antioxidants halt the development of these free radicals called the reactive oxygen species either by chelating the trace elements or by enzymes inhibition.

Objectives: This present review aimed to collect information about Pakistani medicinally important plants with the exploration of their antioxidant potential.

Methodology: A total of 206 papers were looked over, which were obtained from numerous sources like; Google Scholar, Medline, PubMed, Research Gate, Science Direct, Scopus and Web of Science.

Results: Overall, 95 plants representing 44 families with potential antioxidant activity reported from Pakistan have been presented in this review. The maximum number of species from Asteraceae, Poaceae and Rutaceae families were scrutinized for their potential antioxidant activity from Pakistan.

Conclusion: The present review clearly authenticates that the presence of phytochemicals and antioxidant activity of medicinal plants from Pakistan vary with the species of the plants and material/extracts used. From this review, it is recommended to perform comprehensive experimental investigations based on toxicology and ethnopharmacology on these precious plants from Pakistan. It will be advantageous in the provision of trustworthy information to patients and determine further innovative compounds for safer and new drugs development with fewer side effects.

$\begin{array}{lcl}\text { Keywords } & \text { *Address of Correspondence } & \text { Article info. } \\ \text { Antioxidant activity, Flavonoid compounds, } & \text { adil@uo.edu.pk } & \text { Received: February 13, 2020 } \\ \text { Phenolic compounds, Medicinal plants, } & & \text { Accepted: August 21, 2020 } \\ \text { Pakistan } & \end{array}$

Pakistan

Cite this article: Hussain A. A Preliminary Up-To-Date Review on Pakistani Medicinal Plants with Potential Antioxidant Activity. RADS J Biol Res Appl Sci. 2020; 11(1):61-88.

\section{Funding Source: Nil Conflict of Interest: Nil}

This is an Open Access article distributed under the terms of the Creative Commons Attribution License (http://creativecommons.org/licenses/by/4.0), which permits unrestricted use, distribution, and reproduction in any medium provided the original work is properly cited.

\section{INTRODUCTION}

Antioxidants are the compounds that halt the initiation rate of lipid oxidation reactions in the food system. In living organisms, the primary source of health problems is oxidative damage due to the free radicals, and reactive oxygen species (ROS) attack on key macromolecules of the cell. Antioxidants counteract free radicals and are significant in terms of cell prevention from injuries caused by ROS ${ }^{1}$. A group of phytochemicals like amines and phenols are antioxidants, with radical scavenging ability and break down radical chain reactions. These are the substances with significant inhibition of adverse effects caused by the ROS on a human being, and their physiological function. Some antioxidants like reactive oxygen or nitrogen scavengers vitamin $\mathrm{C}$ and $\mathrm{E}$, transition metal chelators and oxidative enzyme (cyclooxygenase) inhibitors are non-enzymatic in nature ${ }^{2}$. The induced ROS 
oxidation disintegrates the cell membrane, damages the membrane protein, and causes mutations in living organism's DNA.

Plants generally contain numerous phytochemicals in their extracts, and their utilization could be fruitful for new therapeutic methodologies development to treat diseases. It could be accomplished only if the antioxidant and antimicrobial profile of the plant is well understood ${ }^{3}$. Antioxidants from plants origin guard the cell by offsetting ROS through scavenging them ${ }^{4}$. Antioxidants from plants are structurally diverse and their activity and extraction dependents on their structure ${ }^{5}$. Total flavonoids and phenols are herbal compounds showing free radical scavenging potential, which are active against neurological disorders 6 . These compounds also act as cardio-protective, antimutagenic and anti-cancerous representatives due to their free radical scavenging ability ${ }^{7}$. Ferreira and Stade ${ }^{8}$ proposed that polyphenolics compounds are chemo-preventive agents because they decrease the level of cholesterol. Because of these unique discoveries, researchers around the world attempts to replace the synthetic antioxidants used in medicinal/foods industries with those of natural healthfriendly antioxidants 6 . According to a survey in Pakistan, 6,000 different types of flowering plants are present, out of which nearly 400-600 species are medicinally important ${ }^{9}$. Additionally, in Pakistan, most of the flora is still unexplored medicinally and their utilization through the Unani Medicine system is still not well documented ${ }^{10}$. In this review, efforts made by the researchers to evaluate the antioxidant efficacy of different plant species from Pakistan have been compiled.

\section{MATERIALS AND METHODS}

The data on different Pakistani plants with antioxidant activity were assembled from search engines like Google Scholar, Scopus, Science Direct, PubMed, Web of Science, Research Gate and Medline. Numerous indicators including "antioxidant activity", "phytochemistry" and "Pakistani medicinal plants" were used to search the data. The correct species names and taxonomic description with synonyms were confirmed from databases (http://www.theplantlist.org/) and (http://www.eflora.org/). About 206 research articles published on the antioxidant activity were studied, and information on the Pakistani medicinal herbs with potential antioxidant activity has been provided.

\section{Pakistani Medicinal Plants with Antioxidant Activity}

Data on 95 plants representing 44 families with potential antioxidant activity reported from Pakistan have been compiled here (Table $1 \&$ Fig. 1). The assembled reported studies concerning antioxidant activities of plants from Pakistan are discussed in detail below:

\section{Acacia leucophloea}

Acacia leucophloea is a species from the Leguminosae family with $\sim 650$ genera and more than 18,000 species ${ }^{11}$. It is one of the major plant families with traditionally used plant species ${ }^{12}$ having medicinal significance ${ }^{13}$. A study from Multan, Pakistan confirmed phenolic compounds existence in A. leucophloea bark methanolic extracts. Antioxidant capacity measured by ferric reducing antioxidant power (FRAP), Trolex equivalent antioxidant capacity (TEAC) and Total peroxyl radical trapping antioxidant parameter (TRAP) assays indicated that the methanolic extracts of $A$. leucophloea stem bark are rich sources of natural antioxidants with acceptable antioxidant activity ${ }^{14}$.

\section{Acacia nilotica}

Acacia nilotica belongs to the plant family Leguminosae. In Bahawalpur, Pakistan, an in vitro antioxidant and antibacterial profile of $A$. nilotica methanolic leaves extract through 2,2-Diphenyl, 1-picrylhydrazyl hydrate (DPPH) inhibition assay showed maximum antioxidant potential with antibacterial activity among tested plant extracts of Leguminosae family ${ }^{15}$.

\section{Adenium obesum (Forssk.)}

Adenium obesum is a plant species from the family Apocynaceae $^{16}$ which is indigenous to South African regions ${ }^{17}$. This plant contains flavonoids, carbohydrates, cardiac glycosides, triterpenes, pregnanes and steroids ${ }^{18}$. In a study from Karachi, Pakistan, the methanolic extracts of $A$. obesum leaves have been evaluated for antioxidant activity with DPPH free radical scavenging assay using standard antioxidants like ascorbic acid and butylated hydroxytoulene (BHT). The tested extracts of $A$. obseum leaves displayed inhibition and better antioxidant activity ${ }^{19}$. A. obesum methanol extract was assessed by 
Ahmed et al., ${ }^{18}$ and described 42 compounds including cardiac glycosides, steroids, and triterpenoids.

\section{Aegle marmelos L.}

Aegle marmelos belongs to the Rutaceae family ${ }^{20}$. This plant is sub-tropical and commonly found in regions of Bangladesh, Bhutan, Burma, Ceylon, India and Pakistan ${ }^{21}$. Rahman et al., ${ }^{22}$ and Khatoon et al., ${ }^{19}$ studied antioxidant efficacy of $A$. marmelos from Pakistan. The antioxidant and lipoxygenase inhibitory potential of some aqueous extracts and organic fractions of mature fruit of A. marmelos have been reported from Karachi, Pakistan ${ }^{22}$. The aqueous and chloroform fractions were supported with greater ability to inhibit soya bean lipoxygenase activity (89-69\%), reduction of free radicals $(88-65 \%)$ and the minimizing of ferric chloride. The methanol extracts of $A$. marmelos were tested from Karachi, Pakistan, with a DPPH assay for assessing free radical scavenging action ${ }^{19}$. All tested extracts of $A$. marmelos validated better radical inhibition action followed by $A$. obseum.

\section{Albizia lebbeck (L.) Benth.}

Albizia lebbeck is a vital species from Mimosaceae family. In many regions of Pakistan, it is grown as an ornamental plant due to pleasant morphology ${ }^{23}$. The antioxidant activity with phytochemistry of $A$. lebbeck extracts was investigated from Pakistan 24,25 . In an inquiry from Multan city of Pakistan, the antioxidant activity of $A$. lebbeck (seed, flower and bark) methanol extracts validated greater phenols. Antioxidant activity estimated by TRAP, TEAC and FRAPS assays, substantiated that the investigated of $A$. lebbeck methanolic extracts are worthy natural antioxidants sources ${ }^{24}$. Another investigation from Multan, Pakistan displayed the antioxidant potential of aqueous methanol pods, stems, and roots extracts of $A$. lebbeck. Studies based on composition specified carbohydrates as the main constituents and saponins as chief antinutrient in both seeds and pods extracts of $A$. lebbeck. In the pods extract and seed oil of $A$. lebbeck, a major fatty acid linoleic acid is present. a-tocopherol is a major tocopherol component in oil. In vitro FRAP, TRAP and TEAC substantiates the aqueous methanol pods, stems and roots extracts of $A$. lebbeck with potent antioxidant activity ${ }^{25}$.

\section{Aloe vera L.}

The Aloe vera plant belongs to the plant family Liliaceae. This plant possesses almost 200 phytochemicals and 70 75 diverse nutrients like anthraquinones, amino acids, lignin, enzymes, minerals, saponins, sugars, salicylic acid and vitamins ${ }^{26}$. Antioxidant activity and phytochemistry of A. vera extracts from Pakistan have been described by Malik et al.. ${ }^{27}$ and Waris et al., ${ }^{28}$. A study from Bhimber AJK of Pakistan ${ }^{27}$ exposed the presence of phytochemicals and nutrients like amino acid, carbohydrates, flavonoids, glycosides, phenolic compounds, steroids, reducing sugar, tannins, saponin and terpenoids in the ethanol, aqueous and methanol and extracts of $A$. vera leaves. Waris et al., ${ }^{28}$ from Peshawar, Pakistan documented the presence of flavonoids, alkaloids, glycosides, saponins and tannins in the $A$. vera plant extracts with antioxidant activity.

\section{Artemisia L. species}

Artemisia genus belongs to the family Asteraceae. Many Artemisia species are significant economically due to their antitumor, antispasmodic, antiseptic, antirheumatic*- and hepato-protective ${ }^{86}$, antioxidant, antihelmintic, anticancerous, antimicrobial and antimalarial possessions ${ }^{87}$. A lot of Artemisia species have been discovered from Pakistan and scrutinized for their antioxidant activity namely Artemisia annua ${ }^{33}$, Artemisia persica ${ }^{30}$, Artemisia roxburghiana ${ }^{31}$ and Artemisia rutifolia ${ }^{34}$. An enquiry from the Islamabad region of Pakistan has been performed for antioxidant activity assessed with Trolox equivalent, DPPH, FRAP and lipid peroxidation assay (LPD). As a result, the maximum total flavonoid contents (TFC), total phenolic contents (TPC), DPPH and TEAC and minimum peroxidation of lipid for the methanol extracts were recorded, however, the aqueous extract showed maximum ferric reducing antioxidant power ${ }^{33}$. Akhtar et al., ${ }^{31}$ checked the presence of phytochemicals with potential antioxidant activity of aqueous and methanol/chloroform extracts of Artemisia roxburghiana from Nathiagali region of Abbotabad, Pakistan. A study from the northern Pakistan displayed that the methanol extracts from leaves of $A$. persica contains phenolics and flavonoids with a startling antioxidant activity ${ }^{30}$. In a study from Chitral KPK, Pakistan, total phenolic and flavonoid contents, antimicrobial activity, DPPH activity and reducing power 
of $A$. rutifolia leaves methanolic extracts showed antioxidant activity 34 .

\section{Berberis lycium (Royle.)}

The plant Berberis lycium is from the genus Berberis of the Berberidaceae family. Studies of Ahmed and Shakeel ${ }^{36}$, Sabir et al., ${ }^{37}$, Akhtar et al.., ${ }^{31}$ and Shan et al.., ${ }^{88}$ validated the potential antioxidant action of $B$. lycium from Pakistan. A noteworthy association amongst phenolic compounds and the antioxidant dimensions substantiated that these are the major factors that provides antioxidant efficacy to the B. lycium (Ahktar et al., 2015). From the north Himalayan region of Pakistan, B. lycium was collected and the total antioxidant activity was scrutinized in its acetone fruit extract. The presence of polyphenolics and the antioxidant activity caused by these compounds discovered a synergistic part of secondary metabolites in inhibiting diseases ${ }^{88}$. Akhtar et al., ${ }^{31}$ from Nathialgali Abbottabad, Pakistan scrutinized the methanol/chloroform and aqueous extracts of $B$. lyceum for its antioxidant activity and corroborated great antioxidant activities in the testes extracts due to better reduction capacity and 2,2-DPPH radical scavenging action. Sabir et al., ${ }^{37}$ extracted six phytochemicals from petroleum ether and methanol extracts of the roots of $B$. lycium in Tehsil Rawalakot, Pakistan and characterized them structurally with the help of low-resolution mass, Infrared, ${ }^{13} \mathrm{C}$ and ${ }^{1} \mathrm{H}$ NMR (Nuclear magnetic resonance) spectroscopy. All the extracted compounds from this plant exhibited prospective antioxidant activity. Another inquiry from Rehar Mansehra KPK, Pakistan inspected the stem and fruit extracts of $B$. lycium and the presence of potential antioxidant compounds with superoxide anion radical scavenging activity has been validated ${ }^{36}$.

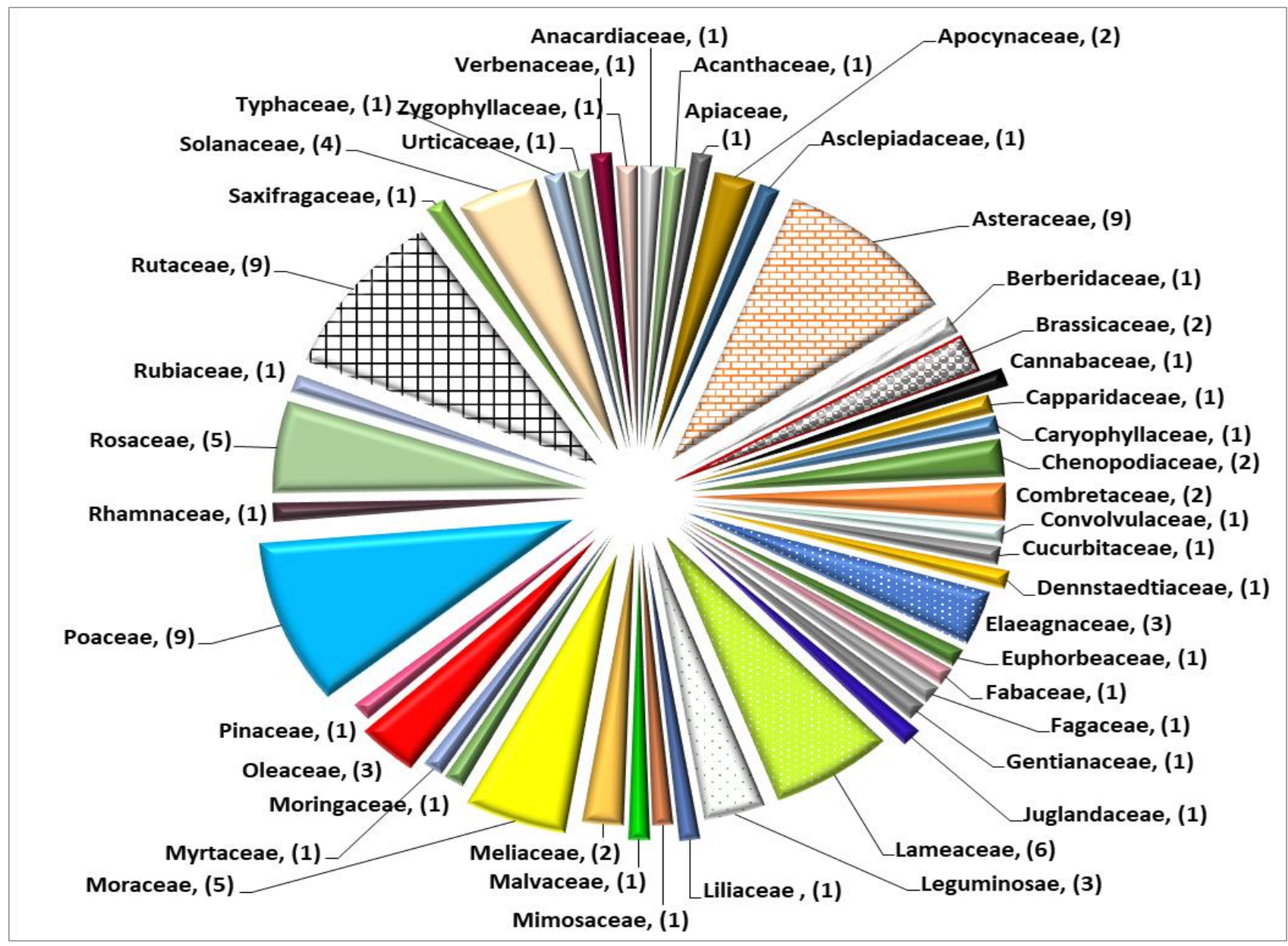

Figure 1. Family-wise distribution of medicinally important plants with potential antioxidant activity reported from Pakistan. The numbers in brackets specify species from the corresponding family. 
Table 1. Reported Plants with Potential Antioxidant Activity from Different Localities of Pakistan.

\begin{tabular}{|c|c|c|c|c|c|c|c|}
\hline S.No. & Family & $\begin{array}{l}\text { No. of } \\
\text { Plants }\end{array}$ & Plant Name & Locality & Parts Used & Extraction Solvent & Reference \\
\hline 1 & Anacardiaceae & 1 & $\begin{array}{c}\text { Pistacia } \\
\text { integerrima (Stew.) }\end{array}$ & Malakand KPK & Fruit & Methanol & 29 \\
\hline 2 & Apiaceae & 1 & $\begin{array}{l}\text { Centella asiatica } \\
\text { (Linn.) Urban Sys. }\end{array}$ & Northern areas & Leaves \& stem & Methanol & 30 \\
\hline \multirow{3}{*}{3} & \multirow{3}{*}{ Apocynaceae } & \multirow{3}{*}{2} & \multirow{2}{*}{$\begin{array}{c}\text { Adenium obesum } \\
\text { (Forssk.) }\end{array}$} & Pakistan & Fruit & Methanol & $18^{*}$ \\
\hline & & & & Karachi & Leaves & Methanol & 19 \\
\hline & & & $\begin{array}{l}\text { Catharanthus } \\
\text { roseus (G. Don) }\end{array}$ & Attock & Whole plant & Methanol/chloroform \& aqueous & 31 \\
\hline \multirow[t]{2}{*}{4} & \multirow[t]{2}{*}{ Acanthaceae } & \multirow[t]{2}{*}{1} & \multirow{2}{*}{$\begin{array}{c}\text { Justicia adhatoda } \\
\text { L. }\end{array}$} & Islamabad & Leaves & $\begin{array}{l}\text { Methanol, ethanol, butanol, chloroform } \\
\text { \& n-hexane }\end{array}$ & 40 \\
\hline & & & & Islamabad & Leaves & Methanol/chloroform \& aqueous & 31 \\
\hline 5 & Asclepiadaceae & 1 & Periploca aphylla & $\begin{array}{c}\text { Toormang, Dir } \\
\text { KPK }\end{array}$ & Aerial part & Methanol & 32 \\
\hline \multirow{9}{*}{6} & \multirow{9}{*}{ Asteraceae } & \multirow{9}{*}{9} & Artemisia annua L. & Islamabad & Leaves & $\begin{array}{l}\text { Hexane, chloroform, ethyl acetate, } \\
\text { methanol \& water }\end{array}$ & 33 \\
\hline & & & Artemisia persica & Northern areas & Leaves \& stem & Methanol & 30 \\
\hline & & & $\begin{array}{c}\text { Artemisia } \\
\text { roxburghiana (Wall. } \\
\text { ex Besser) }\end{array}$ & $\begin{array}{l}\text { Nathiagali } \\
\text { Abbotabad }\end{array}$ & Whole plant & Methanol/chloroform \& aqueous & 31 \\
\hline & & & $\begin{array}{l}\text { Artemisia rutifolia } \\
\text { (Spreng.) }\end{array}$ & Chitral, KPK & Leaves & Methanol, chloroform \& hexane & 34 \\
\hline & & & $\begin{array}{c}\text { Cichorium intybus } \\
\text { L. }\end{array}$ & Gujrat & Whole plant & Methanol & 35 \\
\hline & & & $\begin{array}{l}\text { Cousinia minuta } \\
\text { Boiss }\end{array}$ & Kalahagh & L eaves & \multirow{3}{*}{ Methanol/chloroform \& aqueous } & \multirow{3}{*}{31} \\
\hline & & & $\begin{array}{l}\text { Cirsium arvense } \\
\text { (L.) Scop. }\end{array}$ & Nairanaynt & Leaves & & \\
\hline & & & $\begin{array}{c}\text { Carthamus } \\
\text { oxyacantha } \\
\text { (M.Bieb) }\end{array}$ & Mianwali & Whole plant & & \\
\hline & & & $\begin{array}{c}\text { Pentanema } \\
\text { vestitum (Linn.) }\end{array}$ & Malakand, KPK & Whole plant & Methanol & 29 \\
\hline \multirow{3}{*}{7} & \multirow{3}{*}{ Berberidaceae } & \multirow{3}{*}{1} & \multirow{3}{*}{$\begin{array}{l}\text { Berbaris lycium } \\
\text { (Royle). }\end{array}$} & Mansehra, KPK & Fruit & DMSO & 36 \\
\hline & & & & $\begin{array}{l}\text { Nathiagali } \\
\text { Abbottabad }\end{array}$ & Whole plant & Methanol/chloroform \& aqueous & 31 \\
\hline & & & & Rawalakot & Roots & Methanol \& petroleum ether & 37 \\
\hline \multirow{4}{*}{8} & \multirow{4}{*}{ Brassicaceae } & \multirow{4}{*}{2} & $\begin{array}{c}\text { Brassica } \\
\text { campestris L. }\end{array}$ & Shahdra & Whole plant & Methanol/chloroform \& aqueous & 31 \\
\hline & & & \multirow{3}{*}{$\begin{array}{l}\text { Nasturtium } \\
\text { officinale (W. T. } \\
\text { Aiton) }\end{array}$} & North KPK & Whole plant & Crude ethanol & 38 \\
\hline & & & & Salgira park & Whole plant & Methanol/chloroform \& aqueous & 31 \\
\hline & & & & Tanawal area & Whole plant & Mthanol & 39 \\
\hline \multirow{3}{*}{9} & \multirow{3}{*}{ Cannabaceae } & \multirow{3}{*}{1} & \multirow{3}{*}{ Cannabis sativa L. } & Lahore & Leaves \& stem & Methanol and ethanol & 41 \\
\hline & & & & Bajaur, KPK & Leaves & Methanol, ethanol \& chloroform & $42^{*}$ \\
\hline & & & & Peshawar, KPK & Whole plant & Acetone & 28 \\
\hline \multirow{3}{*}{10} & \multirow{3}{*}{ Capparidaceae } & \multirow{3}{*}{1} & \multirow{3}{*}{$\begin{array}{l}\text { Capparis decidua } \\
\text { (Forsk.) Edgew }\end{array}$} & Multan & $\begin{array}{l}\text { Leaves, flowers } \\
\text { \& fruit }\end{array}$ & Methanol & 43 \\
\hline & & & & Multan & Roots & Methanol & 24 \\
\hline & & & & Mianwali & Bark & Methanol/chloroform \& aqueous & 31 \\
\hline
\end{tabular}

Continue... 


\begin{tabular}{|c|c|c|c|c|c|c|c|}
\hline S.No. & Family & $\begin{array}{l}\text { No. of } \\
\text { Plants }\end{array}$ & Plant Name & Locality & Parts Used & Extraction Solvent & Reference \\
\hline 11 & Caryophyllaceae & 1 & Stellaria media L. & North KPK & Whole plant & Crude ethanol & 38 \\
\hline \multirow{2}{*}{12} & \multirow{2}{*}{ Chenopodiaceae } & \multirow{2}{*}{2} & $\begin{array}{l}\text { Chenopodium } \\
\text { ambrosioides }\end{array}$ & Kotli, AJK & Bark \& fruit & $\begin{array}{l}\text { Aqueous, petroleum ether, chloroform } \\
\text { \& methanol }\end{array}$ & 44 \\
\hline & & & Haloxylon griffithii & Hanna, Quetta & $\begin{array}{l}\text { Leaves, stem \& } \\
\text { roots }\end{array}$ & Methanol & 45 \\
\hline \multirow{2}{*}{13} & \multirow{2}{*}{ Combretaceae } & \multirow{2}{*}{2} & $\begin{array}{l}\text { Conocarpus } \\
\text { lancifolius }\end{array}$ & $\begin{array}{c}\text { Pattoki \& } \\
\text { Lahore }\end{array}$ & Whole plant & Dichloromethane \& methanol & 46 \\
\hline & & & $\begin{array}{l}\text { Terminalia arjuna } \\
\text { L. }\end{array}$ & Faisalabad & $\begin{array}{l}\text { Leaves \& stem } \\
\text { bark }\end{array}$ & Aqueous ethanol \& aqueous methanol & 47 \\
\hline 14 & Convolvulaceae & 1 & $\begin{array}{l}\text { Convolvulus } \\
\text { leiocalycinus }\end{array}$ & Hanna, Quetta & $\begin{array}{l}\text { Leaves, stem \& } \\
\text { roots }\end{array}$ & Methanol & 45 \\
\hline 15 & Cucurbitaceae & 1 & $\begin{array}{l}\text { Momordica } \\
\text { charantia }\end{array}$ & Lahore & $\begin{array}{l}\text { Seed, peel \& } \\
\quad \text { flakes }\end{array}$ & Aqueous & 48 \\
\hline 16 & $\begin{array}{c}\text { Dennstaedtiacea } \\
\mathrm{e}\end{array}$ & 1 & $\begin{array}{l}\text { Pteridium } \\
\text { aquilinum }\end{array}$ & North KPK & Whole plant & Crude ethanol & 38 \\
\hline \multirow{4}{*}{17} & \multirow{4}{*}{ Elaeagnaceae } & \multirow{4}{*}{3} & $\begin{array}{l}\text { Elaeagnus } \\
\text { angustifolia }\end{array}$ & Chitral valley & Fruit & Crude ethanol & 49 \\
\hline & & & $\begin{array}{l}\text { Elaeagnus } \\
\text { umbellate Thunb. }\end{array}$ & Rawlakot, AJK & Fruit & Methanol & 50 \\
\hline & & & \multirow[b]{2}{*}{$\begin{array}{l}\text { Hippophae } \\
\text { rhmnoides L. }\end{array}$} & Skardu & Berries & Methanol & 51 \\
\hline & & & & $\begin{array}{l}\text { Skardu, Gilgit- } \\
\text { Baltistan }\end{array}$ & Leaves & $\begin{array}{l}\text { Aqueous, acetone, ethanol, } \\
\text { chloroform, ethyl acetate, methanol \& } \\
n \text {-hexane }\end{array}$ & 52 \\
\hline 18 & Euphorbeaceae & 1 & Euphorbia royleana & Faisalabad & Whole plant & Methanol, hexane, and aqueous & 34 \\
\hline \multirow{3}{*}{19} & \multirow{3}{*}{ Fabaceae } & \multirow{3}{*}{1} & \multirow{3}{*}{ Cicer arietinum $\mathrm{L}$. } & Mianwali & Leaves \& stem & Methanol/chloroform \& aqueous & 31 \\
\hline & & & & Multan & Seed & Methanol & 24 \\
\hline & & & & Faisalabad & Seed & Acetone & 53 \\
\hline \multirow{2}{*}{20} & \multirow{2}{*}{ Fagaceae } & \multirow{2}{*}{1} & \multirow{2}{*}{$\begin{array}{l}\text { Quercus incana } \\
\text { (Roxb.) }\end{array}$} & Abbottabad & Whole plant & Ethyl acetate \& $n$-butanol & 54 \\
\hline & & & & Pakistan & Bark & Ethyl acetate \& methanol & 55 \\
\hline 21 & Gentianaceae & 1 & $\begin{array}{l}\text { Swertia chirata } \\
\text { (Roxb.) }\end{array}$ & Galyat, KPK & Aerial part & Methanol & 56 \\
\hline 22 & Juglandaceae & 1 & Juglans regia & Chitral valley & Fruit & Crude ethanol & 49 \\
\hline \multirow{6}{*}{23} & \multirow{6}{*}{ Lamiaceae } & \multirow{6}{*}{6} & $\begin{array}{c}\text { Colebrookea } \\
\text { oppositifolia (Sm). }\end{array}$ & Islamabad & Leaves \& flower & \multirow[t]{2}{*}{ Methanol/chloroform \& aqueous } & \multirow[t]{2}{*}{31} \\
\hline & & & Mentha piperita L. & Rawalpindi & Whole plant & & \\
\hline & & & Mentha Iongifolia L. & Peshawar & Whole plant & Acetone & 28 \\
\hline & & & Mentha spicata & $\begin{array}{l}\text { Muzaffarabad, } \\
\text { AJK }\end{array}$ & Leaves & $\begin{array}{l}\text { Diethyl ether, chloroform, ethanol \& } \\
\text { methanol }\end{array}$ & 57 \\
\hline & & & $\begin{array}{l}\text { Origanum } \\
\text { majorana L. }\end{array}$ & \multirow{2}{*}{ Faisalabad } & \multirow{2}{*}{ Aerial part } & \multirow{2}{*}{ Essential oil } & \multirow{2}{*}{58} \\
\hline & & & $\begin{array}{c}\text { Origanum vulgare } \\
\text { L. }\end{array}$ & & & & \\
\hline \multirow{3}{*}{24} & \multirow{3}{*}{ Leguminosae } & & Acacia leucophloea & Multan & Stem bark & Methanol & 24 \\
\hline & & 3 & Acacia nilotica & Bahawalpur & Leaves & Methanol & 15 \\
\hline & & & Trifolium repens & $\begin{array}{l}\text { North Khyber } \\
\text { Pakhtunkhwa }\end{array}$ & Whole plant & Ethanol & 38 \\
\hline 25 & lil & 1 & pyeral & Bhimber, AJK & Leaves & Ethanol \& methanol & $27^{*}$ \\
\hline 20 & Limauced & 1 & תive verat. & Peshawar, KPK & Leaves & Acetone & 28 \\
\hline
\end{tabular}

Continue... 


\begin{tabular}{|c|c|c|c|c|c|c|c|}
\hline S.No. & Family & $\begin{array}{l}\text { No. of } \\
\text { Plants }\end{array}$ & Plant Name & Locality & Parts Used & Extraction Solvent & Reference \\
\hline \multirow{2}{*}{26} & \multirow{2}{*}{ Meliaceae } & \multirow{2}{*}{2} & Melia azedarach & Faisalabad & $\begin{array}{l}\text { Leaves, fruit \& } \\
\text { stem bark }\end{array}$ & Aqueous methanol & 59 \\
\hline & & & $\begin{array}{l}\text { Azadirachta indica } \\
\text { A. Juss. }\end{array}$ & Mianwali & Leaves & $\begin{array}{c}\text { Methanol/chloroform \& } \\
\text { aqueous }\end{array}$ & 31 \\
\hline \multirow{2}{*}{27} & \multirow{2}{*}{ Malvaceae } & \multirow{2}{*}{1} & \multirow{2}{*}{ Grewia asiatica L. } & Mianwali & Leaves & $\begin{array}{c}\text { Methanol/chloroform \& } \\
\text { aqueous }\end{array}$ & 31 \\
\hline & & & & Multan & Leaves & Methanol & 24 \\
\hline \multirow{2}{*}{28} & \multirow{2}{*}{ Mimosaceae } & \multirow{2}{*}{1} & \multirow{2}{*}{$\begin{array}{l}\text { Albizia lebbeck (L.) } \\
\text { Benth. }\end{array}$} & Multan & $\begin{array}{l}\text { Pod, stem \& } \\
\text { roots }\end{array}$ & Aqueous methanol & 25 \\
\hline & & & & Multan & $\begin{array}{l}\text { Bark, flower \& } \\
\text { seed }\end{array}$ & Methanol & 24 \\
\hline \multirow{6}{*}{29} & \multirow{6}{*}{ Moraceae } & \multirow{6}{*}{5} & Fiscus carica & Bannu, KPK & Fruit & Aqueous methanol & 60 \\
\hline & & & $\begin{array}{c}\text { Ficus } \\
\text { sarmentosa }\end{array}$ & $\begin{array}{l}\text { Toormang, Dir } \\
\text { KPK }\end{array}$ & Aerial part & Methanol & 32 \\
\hline & & & $\begin{array}{c}\text { Ficus } \\
\text { microcarpaa L. } \\
\text { (fil) }\end{array}$ & Islamabad & Whole plant & $\begin{array}{c}\text { Methanol/chloroform \& } \\
\text { aqueous }\end{array}$ & 31 \\
\hline & & & \multirow{2}{*}{ Morus alba } & Mardan & Leaves & Aqueous extract & $61^{*}$ \\
\hline & & & & Chitral valley & Fruit & Crude ethanol & 49 \\
\hline & & & Morus nigra & Islamabad & Whole plant & $\begin{array}{c}\text { Methanol/chloroform \& } \\
\text { aqueous }\end{array}$ & 31 \\
\hline \multirow[b]{2}{*}{30} & \multirow[b]{2}{*}{ Moringaceae } & \multirow[b]{2}{*}{1} & \multirow{2}{*}{$\begin{array}{l}\text { Moringa oleifera } \\
\text { (Lam.) }\end{array}$} & Faisalabad & Leaves & Ethanol & 62 \\
\hline & & & & $\begin{array}{l}\text { Kundian } \\
\text { Mianwali }\end{array}$ & Whole plant & $\begin{array}{c}\text { Methanol/chloroform \& } \\
\text { aqueous }\end{array}$ & 31 \\
\hline \multirow{2}{*}{31} & \multirow{2}{*}{ Myrtaceae } & \multirow{2}{*}{1} & \multirow{2}{*}{ Psidium guajava } & Mardan & Leaves & Aqueous extract & $61^{*}$ \\
\hline & & & & Chitral valley & Fruit & Crude ethanol & 49 \\
\hline \multirow{3}{*}{32} & \multirow{3}{*}{ Oleaceae } & \multirow{3}{*}{3} & $\begin{array}{l}\text { Jasminum } \\
\text { humile }\end{array}$ & Abbottabad & Flower & $\begin{array}{c}\text { Ethyl acetate, } n \text {-butanol \& } \\
n \text {-hexane }\end{array}$ & 35 \\
\hline & & & $\begin{array}{l}\text { Jasminum } \\
\text { officinale L. }\end{array}$ & & & & \\
\hline & & & $\begin{array}{c}\text { Jasminum } \\
\text { Sambac L. } \\
\text { (Aiton) }\end{array}$ & Mianwali & Whole plant & $\begin{array}{c}\text { Methanol/chloroform \& } \\
\text { aqueous }\end{array}$ & 31 \\
\hline \multirow{2}{*}{33} & \multirow{2}{*}{ Pinaceae } & \multirow{2}{*}{01} & \multirow{2}{*}{$\begin{array}{l}\text { Cedrus deodara } \\
\text { (Roxb. ex D. } \\
\text { Don) }\end{array}$} & $\begin{array}{l}\text { Rawalakot } \\
\text { AJK }\end{array}$ & Stem \& leaves & Aqueous extracts \& oil & 63 \\
\hline & & & & $\begin{array}{l}\text { Northern } \\
\text { areas }\end{array}$ & Stem \& leaves & Methanol & 30 \\
\hline
\end{tabular}

Continue... 


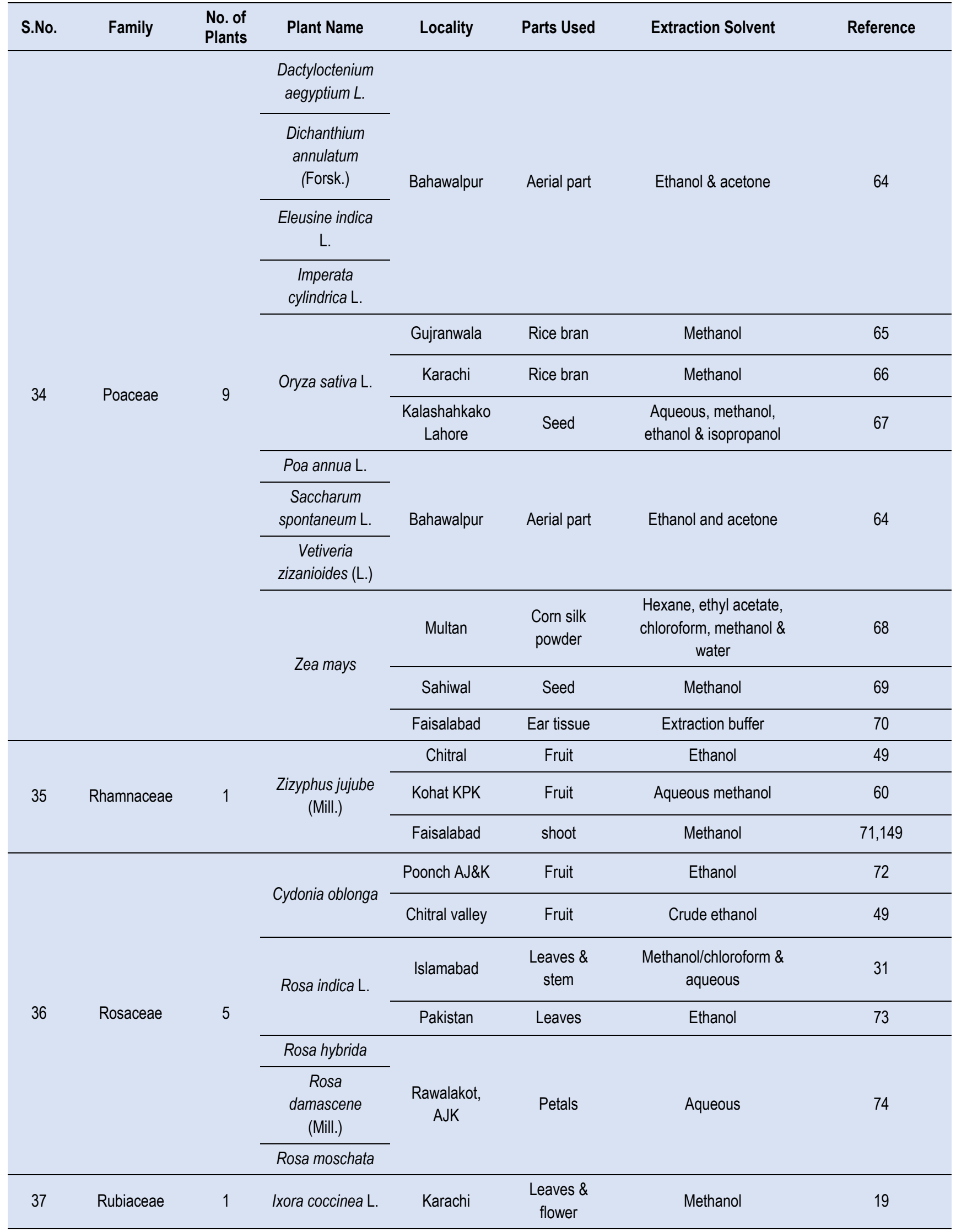

Continue... 


\begin{tabular}{|c|c|c|c|c|c|c|c|}
\hline S.No. & Family & $\begin{array}{l}\text { No. of } \\
\text { Plants }\end{array}$ & Plant Name & Locality & Parts Used & Extraction Solvent & Reference \\
\hline \multirow{5}{*}{38} & \multirow{5}{*}{ Rutaceae } & \multirow{5}{*}{9} & \multirow{2}{*}{$\begin{array}{c}\text { Aegle marmelos } \\
\mathrm{L} .\end{array}$} & Karachi & Fruit & Crude aqueous & 22 \\
\hline & & & & Karachi & Fruit & Methanol & 19 \\
\hline & & & $\begin{array}{c}\text { Citrus sinensis } \\
\text { (var. Valencia), } \\
\text { Citrus sinensis } \\
\text { (var. Sungin), } \\
\text { Citrus sinensis } \\
\text { (var. Washington } \\
\text { Navel), Citrus } \\
\text { reticulata (var. } \\
\text { Page), Citrus } \\
\text { aurantium and } \\
\text { Citrus paradise }\end{array}$ & Sargodha & Peel \& fruit & Methanol & 75 \\
\hline & & & Citrus sinensis & Islamabad & Powder & Methanol & 76 \\
\hline & & & $\begin{array}{l}\text { Citrus limon L. } \\
\text { (Burm.f.) }\end{array}$ & Malakwal & Whole plant & $\begin{array}{c}\text { Methanol/chloroform \& } \\
\text { aqueous }\end{array}$ & 31 \\
\hline \multirow{2}{*}{39} & \multirow{2}{*}{ Saxifragaceae } & \multirow{2}{*}{1} & \multirow{2}{*}{$\begin{array}{l}\text { Bergenia ciliata } \\
\text { (haw.) Sternb }\end{array}$} & $\begin{array}{l}\text { Nathiagali, } \\
\text { KPK }\end{array}$ & Rhizome & Methanol & 77 \\
\hline & & & & Kaghan valley & Rhizome & $\begin{array}{l}\text { Methanol, chloroform, ethyl } \\
\text { acetate \& } n \text {-hexane }\end{array}$ & 56 \\
\hline \multirow{9}{*}{40} & \multirow{9}{*}{ Solanaceae } & \multirow{9}{*}{4} & \multirow{3}{*}{$\begin{array}{l}\text { Datura innoxia } \\
\text { (Mill.) }\end{array}$} & Islamabad & $\begin{array}{l}\text { Leaves \& } \\
\text { stem }\end{array}$ & $\begin{array}{c}\text { Distilled water chloroform, } \\
n \text {-hexane, } \\
\text { ethyl acetate, acetone, } \\
\text { ethanol \& methanol }\end{array}$ & 78 \\
\hline & & & & Bahawalpur & Fruit \& leaves & Ethanol & 79 \\
\hline & & & & Mianwali & Whole plant & $\begin{array}{c}\text { Methanol/chloroform \& } \\
\text { aqueous }\end{array}$ & 31 \\
\hline & & & \multirow{2}{*}{$\begin{array}{c}\text { Solanum nigrum } \\
\mathrm{L} .\end{array}$} & $\begin{array}{l}\text { Mirpur } \\
\text { Bhimber }\end{array}$ & $\begin{array}{l}\text { Fruit, leaves } \\
\text { and stem }\end{array}$ & $\begin{array}{l}\text { Chloroform, distilled water } \\
\text { ethanol \& petroleum ether }\end{array}$ & $80^{*}$ \\
\hline & & & & Bahalwalpur & Fruit \& leaves & Ethanol & 79 \\
\hline & & & \multirow{2}{*}{$\begin{array}{c}\text { Withna } \\
\text { somnifera }\end{array}$} & $\begin{array}{l}\text { Malakand, } \\
\text { KPK }\end{array}$ & Fruit & Methanol & 29 \\
\hline & & & & Bahalwalpur & Fruit \& leaves & Ethanol & 79 \\
\hline & & & \multirow{2}{*}{$\begin{array}{c}\text { Withna } \\
\text { coagulans } \\
\text { (Dunal.) }\end{array}$} & Mianwali & Whole plant & $\begin{array}{c}\text { Methanol/chloroform \& } \\
\text { aqueous }\end{array}$ & 31 \\
\hline & & & & $\begin{array}{l}\text { Malakand } \\
\text { KPK }\end{array}$ & Fruit & Methanol & 29 \\
\hline 41 & Typhaceae & 1 & $\begin{array}{c}\text { Typha } \\
\text { domigensis } \\
\text { (Pers.) }\end{array}$ & Lahore & Pollen & $\begin{array}{l}\text { Chloroform, methanol, ethyl } \\
\text { acetate } n \text {-hexane \& water }\end{array}$ & 81 \\
\hline \multirow[b]{2}{*}{42} & \multirow[b]{2}{*}{ Urticaceae } & \multirow[b]{2}{*}{1} & \multirow{2}{*}{ Urtica dioica L. } & Islamabad & Aerial part & Ethanol & $82^{*}$ \\
\hline & & & & $\begin{array}{l}\text { North Khyber } \\
\text { Pakhtunkhwa }\end{array}$ & Whole plant & $\begin{array}{l}\text { Crude ethanol, } n \text {-hexane, } \\
\text { ethyl acetate } \& \text { chloroform }\end{array}$ & 38 \\
\hline
\end{tabular}

Continue... 


\begin{tabular}{|c|c|c|c|c|c|c|c|}
\hline S.No. & Family & $\begin{array}{l}\text { No. of } \\
\text { Plants }\end{array}$ & Plant Name & Locality & Parts Used & Extraction Solvent & Reference \\
\hline \multirow[b]{2}{*}{43} & \multirow[b]{2}{*}{ Verbenaceae } & \multirow[b]{2}{*}{1} & \multirow{2}{*}{$\begin{array}{c}\text { Lantana camara } \\
\text { L. }\end{array}$} & $\begin{array}{c}\text { Soon Sakesar } \\
\text { Punjab }\end{array}$ & Flower \& fruit & Methanol and ethanol & 83 \\
\hline & & & & Karachi & Aerial part & $\begin{array}{l}\text { Methanol, aqueous, } \\
\text { petroleum ether \& ethyl } \\
\text { acetate }\end{array}$ & 84 \\
\hline 44 & Zygophyllaceae & 1 & $\begin{array}{c}\text { Fagonia cretica } \\
\text { L. }\end{array}$ & Hazara & Stem \& spines & $\begin{array}{c}\text { Aqueous \& } \\
\text { methanol/chloroform }\end{array}$ & 31 \\
\hline
\end{tabular}

${ }^{*}$ Represents studies concerning only phytochemical investigations of the plants

\section{Bergenia ciliata (haw.) Sternb}

Bergenia ciliata is a species of the genus Bergenia from Saxifragaceae family. In Pakistan, two species of the genus Bergenia are locally distributed like $B$. strachey and B. ciliata ${ }^{89}$. Inquiries of Khan et al., ${ }^{56}$ and Ahmed et al., ${ }^{77}$ acknowledged the phytochemistry and antioxidant profile of $B$. ciliate from Pakistan. Investigation of methanol crude extracts and chloroform, $n$-hexane and ethyl acetate fractions of rhizome of $B$. ciliata from Kaghan valley (KPK) Pakistan proposed that the chloroform fraction is highly anti-oxidative with the $\mathrm{IC}_{50}$ value of $4.15 \pm 0.82$ as compared to ethyl acetate ${ }^{56}$. In an inquiry from Nathiagali KPK, Pakistan, the improved free radical inhibition percentage with DPPH assay with high flavonoid and phenolic contents validated the antioxidant potential of $B$. ciliate. The aqueous and ethyl acetate extracts have been corroborated with better activity against $\mathrm{H} 157$ cell line ${ }^{77}$. According to Rauf et al., ${ }^{32}$ flavonoids such as quercetin from $B$. Ciliata remarkably holds antiradical, antioxidant, and iron-chelating properties.

\section{Brassica campestris L.}

Brassica campestris belongs to the family Brassicaceae. The samples of $B$. campestris from Shahdra, Pakistan showed promising antioxidant efficacy in the tested extracts with better reduction and total antioxidant activities due to phenolics and flavonoids presence ${ }^{31}$.

\section{Cannabis sativa $\mathrm{L}$.}

Cannabis sativa is an important dioicous species from the Cannabis genus of the family Cannabaceae. This plant is extensively distributed globaly ${ }^{90}$ including Pakistan ${ }^{91}$. Many researchers $28,41,42,91$ documented the antioxidant activity and phytochemical profile of $C$. sativa from Pakistan. An antioxidant investigation from Lahore,
Pakistan using DPPH scavenging assay showed that the ethanol extracts of $C$. sativa leaves retain great antimicrobial activity and contains natural antioxidants ${ }^{41}$. In Bajaur agency of Pakistan, the ethanol, methanol and chloroform leaf extracts of $C$. sativa were scrutinized that validated the presence of important phytochemicals. The presence of alkaloids, cardiac glycosides, carbohydrates, flavonoids, phlobatannins, proteins, phenols, saponin, terpenoids and tannins was confirmed in C. sativa leaf extracts $^{42}$. Another phytochemical inquiry authenticated the presence of alkaloids, glycosides and saponins in extracts of $C$. sativa. Antioxidant activity with DPPH assay specified that this plant holds a promising antioxidant activity 28 .

\section{Capparis decidua (Forsk.) Edgew}

Capparis decidua from Capparidaceae family is a drought resistant plant grown as dense tufts in dry areas of Pakistan ${ }^{92}$. In Pakistan, Akhtar et al., ${ }^{31}$, Imran et al., ${ }^{24}$ and Haq et al., ${ }^{43}$ documented the antioxidant activity and phytochemistry $C$. decidua extracts. An in vitro antioxidant investigation of roots methanolic extracts of $\mathrm{C}$. decidua from Multan, Pakistan corroborated the phenolic compounds presence. Antioxidant capacity measured by FRAP, TEAC and TRAP assays indicated that the root extracts of $C$. decidua are good sources of natural antioxidants ${ }^{24}$. Another inquiry from Multan, Pakistan exposed presence of amino acids, proximate chemicals, fatty acids, sterols and tocopherols in seeds oil and TPC and Total Glucosinolates (TG) in methanol extracts of $C$. decidua. The antioxidant activity validated remarkable antioxidant activity of $C$. desidua extracts due to the presence of phenolics and glucosinates with potent antidiabetic and antihemolytic activity ${ }^{43}$. Akhtar et al., ${ }^{31}$ 
validated bark extracts of $C$. decidua with antioxidant action from Mianwali city of Pakistan.

\section{Carthamus oxyacantha (M.Bieb)}

Carthamus oxyacantha belongs to the family Asteraceae. In Pakistan, Akhter et al., ${ }^{31}$ have described the antioxidant potential of $C$. oxyacantha. They collected samples of C. oxyacantha from Mianwali city of Pakistan and checked the presence of phenols and flavonols in methanol/chloroform and aqueous extract with potential antioxidant activity. They confirmed presence of phenols and flavonoids in the C. oxyacantha plant with antioxidant activities in its methanol/chloroform and aqueous extracts due to reduction and total antioxidant capacity.

\section{Catharanthus roseus (G. Don)}

Catharanthus roseus belongs to the genus Catharanthus of the family Apocynaceae. It has wide-ranging biological activities like antibacterial, antifungal, antiviral and antioxidantal ${ }^{71}$. Akhtar et al., ${ }^{31}$ reported the antioxidant activity of this important plant from Attock city of Pakistan. The extracts (methanol/chloroform and aqueous extract) demonstrated potential antioxidant actions due to their great reduction, total antioxidant capacity and scavenging of 2,2-diphenyl-2-picrylhydrazyl radicals.

\section{Cedrus deodara (Roxb. ex D. Don)}

Cedrus deodara is a species of Pinaceae family. Flavonoid like quercetin, taxifolin and saponins are the major phytochemicals of $C$. deodara. Phytosterols present in this plant are very operative against hyperlipidemia ${ }^{93}$. C. deodara ethanol wood extracts also holds a significant anti-spasmodic activity ${ }^{94}$. The antioxidant activity and phytochemistry of $C$. deodara extracts have was studied by Zaman et al., ${ }^{95}$ and Raza et al., ${ }^{30}$ from Pakistan. An inquiry from district Poonch, Rawalakot Azad Kashmir, Pakistan evaluated the biological activities of $C$. deodara aqueous stem, leaves extracts and essential oil. The crude leaves and stem extracts and essential oil are authenticated with phenolics and flavonoids exhibiting metal chelating and antioxidant activity ${ }^{95}$. Samples of C. deodara collected from Northern areas of Pakistan showed flavonoids and phenolics presence in stems and leaves methanol extracts retaining antioxidant activity.

\section{Centella asiatica (Linn.)}

The plant Centella asiatica is from the Centella genus of the Apiaceae family. The phytochemicals present in this plant encouraged many researchers with the aim of exploring its antioxidant potential ${ }^{96}$. A study from Northern Pakistan suggests that $C$. asiatica extracts are good antioxidants source in food preservation because the leaves and stem methanol extracts hold antioxidant activity in foods rich with fats and oil ${ }^{30}$.

\section{Chenopodium ambrosioides}

Chenopodium ambrosioides is a species from Chenopodiaceae family containing 103 genera and 1300 species found all over the world. In Pakistan, 35 genera and 106 species of this family are present. They are mainly found along sea shores and in the desert or semi desert areas ${ }^{97}$. C. ambrosioides fruit and bark collected from Kotli, AJK, Pakistan were evaluated for antioxidant and antimicrobial potential using aqueous, chloroform, petroleum ether and methanol extracts. The fruit and bark aqueous extracts with greater antioxidant activity was documented ${ }^{44}$.

\section{Cicer arietinum $\mathrm{L}$.}

Cicer arietinum belongs to the Leguminosae family. Legumes including $C$. arietinum possess polyphenolic compounds like flavone, glycosides, flavonols, polymeric and oligomeric proanthocyanidins ${ }^{98}$. In Pakistan, C. arietinum (Chickpeas) are grown as major legume crop $^{99}$ and several chickpea varieties are prevalently consumed as a dietary protein source. Methanol/chloroform and aqueous leaves and stem extracts of this plant assessed from Mianwali, Pakistan corroborated the presence of antioxidant inducing flavonols and phenolic with great antioxidant and reduction abilities ${ }^{31}$. In an inquiry from Multan, Pakistan, an in vitro antioxidant activity of $C$. arietinum seeds methanol extracts corroborated the presence of phenols. Studies validated that $C$. arietinum extracts possesess great antioxidant potential24. Haq et al., ${ }^{53}$ studied the antioxidant action of seed acetone extracts of four indigenous desi chickpeas varieties from Faisalabad, Pakistan showing total phenolic, condensed tannin and flavonoid content with antioxidant activity. 


\section{Cichorium intybus L.}

Cichorium intybus is a species from the Asteraceae family. This plant holds great biological significance because of having flavonoids, alkaloids and vitamin $A, E$ \& $C$ which are antioxidants in nature 35,100 . More specifically, the hydro-alcoholic extracts of $C$. intybus legitimate the presence of phytochemicals with potential antioxidant activity ${ }^{100}$. The antioxidant prospective of crude methanolic extracts of whole plant of $C$. intybus from Gujrat, Pakistan was evaluated through DPPH on TLC assay for their antioxidant actions. The Total Phenolic Contents (TPC) of $C$. intybus calculated and acknowledged as the rich source of innocuous natural antioxidants ${ }^{35}$.

\section{Cirsium arvense (L.) Scop.}

Cirsium arvense plant belongs to the Asteraceae family also called creeping thistle. Samples obtained from Kalabagh, Pakistan revealed that the presence of flavonoids and phenolics in aqueous methanol extracts are crucil features providing antioxidant activity to this plant with great reduction potential ${ }^{31}$.

\section{Citrus L. Species}

The Citrus species belongs to the family Rutaceae. It is used as an anti-diabetic, antifungal, anti-microbial, antioxidant, hypotensive, insect repellent and anti-yeast agent. Investigations of Akhtar et al., ${ }^{31}$, Asjad et al., ${ }^{75}$, Shah et al., ${ }^{76}$ and Mehmood et al., ${ }^{101}$ validated the antioxidant activity of Citrus species from Pakistan. The Azinobis-3-ethylbenzothiazoline-6-sulfonate (ABTS) and DPPH free radical scavenging approaches with Citrus species unveiled their antioxidant and phytochemicals profile that could be fruitful in the prevention fatal diseases like cancer, cardiovascular disorder and diseases related to stress caused by radicals ${ }^{101}$. In Pakistan, C. sinensis species collected from Islamabad, Pakistan substantiated the presence of flavonoids in its crude methanol extracts from plants powder and their scrutiny revealed a potential antioxidant activity ${ }^{76}$. Samples of C. limo collected from Malakwal city were analyzed for antioxidant potential of aqueous and methanol-chloroform extracts where the presence of flavonoids and phenols validated antioxidant activities due to the reduction and total antioxidant abilities ${ }^{31}$. In Sargodha, Pakistan, the fruits and peels of different Citrus species like C. sinensis var. Washington Navel, C. sinensis var. Valencia, C. reticulata var. Page, C. paradise, C. aurantium and C. sinensis var. Sungin scrutinized with methanol proved promising antioxidant activity of the extracts ${ }^{75}$.

\section{Colebrookea oppositifolia (Sm).}

Colebrookia oppositifolia belongs to Lamiaceae family. C. oppositifolia root extracts contains flavones and are employed for epilepsy treatment ${ }^{102}$. In Pakistan, C. oppositifolia whole plant evaluated from Kotli, AJK confirmed cardiac glycosides, flavonoids and phenolics in ethyl acetate, $n$-butanol and chloroform fraction. The soluble ethyl acetate fractions showwed greater percentage inhibition of FRAP, DPPH value and inhibition of lipids peroxidation. The chloroform fraction also holds highest total phenolic contents with highest total antioxidant activity ${ }^{103}$. This species from Islamabad, Pakistan scrutinized for the antioxidant activity of its aqueous and methanol/chloroform leaves and flower extracts displayed phenolic and flavonoid compounds with antioxidant efficacy ${ }^{31}$.

\section{Conocarpus lancifolius}

The Conocarpus genus is from the Combretaceae family having only two species ${ }^{104}$. In a study from Pakistan, C. lancifolius collected from Pattoki and Lahore, elucidated the antioxidant potential of whole plant's methanol and dichloromethane extracts in correlation with total flavonoid and phenolic content. Presence of highest phenolic contents and flavonoid with greater hydroxyl radical and DPPH scavenging actions of the methanolic extracts has been validated ${ }^{105}$.

\section{Convolvulus leiocalycinus}

Convolvulus leiocalycinus is member of the family Convolvulaceae. Convolvulus is a genus consisting of nearly 200-250 species of flowering plants. A study from Hanna Quetta, Pakistan, assessed the antioxidant potentials of methanol extracts of $C$. leiocalycinus through the DPPH, FRAP and phosphomolybdenum assay. The DPPH assay showed C. leiocalycinus with activity of $97.16 \%$ at concentration of $1.0 \mathrm{mg} / \mathrm{ml}$. However, the increased FRAP value for $\mathrm{C}$. leiocalycinus extract proved to have greater antioxidant activity ${ }^{45}$. 


\section{Cousinia minuta (Boiss.)}

Cousinia minuta is a vital member of the family Asteraceae. A study from Kalabagh, Pakistan confirmed phenolic compounds and flavonoids presence in its aqueous and methanol/chloroform leaves extracts with potential antioxidant actions ${ }^{31}$.

\section{Cydonia oblonga (Quince)}

Cydonia oblonga belongs to the Rosaceae family. It is a significant dietary source of essential phytochemicals including phenolic acids and flavonoids ${ }^{106}$. In Pakistan, Rahman et al., ${ }^{49}$ and Rasheed et al., 72 investigated the antioxidant activity of $\mathrm{C}$. oblonga. An attempt from the Chitral valley of Pakistan performed a DPPH scavenging assay of $C$. oblonga crude ethanol extract that validated maximum activity of $27.18 \%$ at $500 \mu \mathrm{g} / \mathrm{ml}$ and minimum activity $9.70 \%$ at $100 \mu \mathrm{g} / \mathrm{ml}$. It has been elucidated that C. oblonga plant possesses great free radical scavenging properties ${ }^{49}$. The mature fruits of $C$. oblonga collected from different locations of Poonch AJK, Pakistan, evaluated for physicochemical analysis revealed the presence of certain compounds and essential nutrients. The phenolic content (gallic acid) present in fruit of this plant possesses potential antioxidant ${ }^{72}$.

\section{Dactyloctenium aegyptium $\mathrm{L}$.}

Dactyloctenium aegyptium belongs to the Poaceae family. It has antipyretic, anti-inflammatory, anticancer, antioxidant and antimicrobial properties. D. aegyptium is employed as a traditional medicine against smallpox and ulcers $^{107}$. In an investigation from Bahawalpur, Pakistan, Fatima et al., ${ }^{64}$ evaluated the aerial parts of $D$. aegyptium plants with ethanol and acetone to assess phytochemicals with antioxidant activity. Secondary metabolites with elevated antioxidant potential have been documented in ethanol and acetone extracts of D. aegyptium ${ }^{64}$.

\section{Datura innoxia (Mill.)}

Datura innoxia is a member of the Solanaceae family ${ }^{108}$. Studies of Akhtar et al., ${ }^{31}$, Fatima et al., ${ }^{78}$ and Fatima et al., ${ }^{64}$ acknowledged the antioxidant activity of $D$. innoxia from different regions of Pakistan. In Pakistan, samples of D. innoxia from Mianwali, Pakistan were checked for antioxidant activity showing better antioxidant potential due to its great reduction capabilies ${ }^{31}$. Different leaves and stem extracts of $D$. innoxia were screened for phytochemical and assessed for their antioxidant potential from Islamabad, Pakistan. The combined acetone and ethyl acetate stem extracts of $D$. innoxia proved maximum $\mathrm{DPPH}$ radical scavenging activity with $\mathrm{IC}_{50}$ values of $16.14 \mu \mathrm{g} / \mathrm{ml}$. Moreover, the ethyl acetate stem and aqueous leaf extracts of $D$. innoxia are considered to possess maximum reducing power and antioxidant actions $^{78}$. In Bahawalpur, Pakistan, the antioxidant activity of $D$. innoxia leaves and fruits ethanolic extracts with 1 , 1-diphenyl-2-picrylhydrazyl assay was measured where maximum activity was validated in its ethanol fruits and leaves extracts ${ }^{79}$.

\section{Dichanthium annulatum (Forsk.)}

Dichanthium annulatum belongs to the family Poaceae. In an inquiry from Bahawalpur, Pakistan, the aerial parts of $D$. annulatum extracted with ethanol and acetone showed secondary metabolites in the extracts of plant. Greater level of antioxidant activity with DPPH, ABTS, NBT and reducing power assay has been validated for ethanol and acetone extracts of $D$. annulatum ${ }^{64}$.

\section{Elaeagnus species}

Elaeagnus species are members of the Elaeagnaceae family. The fruits of many species of the genus Elaeagnus are sweet and contain vitamins $C$ and vitamin $E$. Flavonoids and alkaloids are also present in it. Rahman et al., ${ }^{49}$ documented the antioxidant action of crude ethanol extract of $E$. angustifolia from Chitral valley of Pakistan. Their results showed great antioxidant activity of this plant extracts. In one study, the radical scavenging activity and presence of phytochemicals from berries extract of Elaeagnus umbellate with methanol was validated from Rawlakot, AJK, Pakistan. A conspicuous DPPH scavenging activity and presence of alkaloid, flavonoid, phenolic, carotenoid, saponin and tannin contents made this plant a worthy natural asset with potential antioxidant activity ${ }^{50}$.

\section{Eleusine indica L.}

The plant Eleusine indica is from Poaceae family. Fatima et al., ${ }^{64}$ screened and evaluated the aerial parts of E. indica plants form Bahawalpur, Pakistan, extracted with ethanol and aceton for phytochemical and antioxidant activity. Secondary metabolites presence has been 
confirmed in extracts of plant. An acceptable range of antioxidant activity and reducing power assay has been authenticated in the acetone and ethanol extracts of E. indica.

\section{Euphorbia royleana}

Euphorbia royleana from the family Euphorbeaceae has been utilized as traditional medicine against anemia, asthma, cough, and constipation, jaundice and skin problems ${ }^{109}$. An evaluation of antioxidant, antitumor and antimicrobial activities of hexane, methanol and aqueous extracts of $E$. royleana whole plant has been performed from Faisalabad, Pakistan. Antioxidant activity assessed by DPPH and ferric ions reduction assay, validated a linear increase in inhibition values with increase in extract concentration. The ferric reducing assay of hexane extract substantiated with supreme ferric reducing power of 12.70 $\pm 0.49 \mathrm{mg}$ equivalents to gallic acid. Maximum flavonoid content of $63.68 \pm 0.43 \mathrm{mg}$ equivalents of querectin and phenolic content of $47.47 \pm 0.71 \mathrm{mg}$ as equivalents of gallic acid were confirmed in the hexane extract ${ }^{110}$.

\section{Fagonia cretica L.}

Fagonia cretica is a vital member of the Zygophyllaceae family. In one study 85 from District Layyah, Pakistan, samples of $F$. cretica collected were assessed for antioxidant potentials of its methanol extracts of roots, fruit and upper parts. The total flavonoid and phenolic content values for methanol extracts and numerous fractions of roots and aerial part displayed prodigious total flavonoid and phenolic contents. All the tested extracts and fractions of $F$. cretica particularly, the root extracts have extraordinary antioxidant and radical scavenging capabilities $^{85}$. Akhtar et al., ${ }^{31}$ collected samples of F. cretica from Hazara, Pakistan and determined the antioxidant activity of the stem and spines methanol/chloroform extracts. They confirmed that the plant extracts contains flavonoids and phenols that gives antioxidant activity due to the reduction and total antioxidant abilities.

\section{Ficus L. species}

Ficus species belongs to the Moracea family. Species of this genus possess a material that provides self healing tendency and protection to the plant from foreign attacks $^{111}$. Rauf et al., ${ }^{32}$ and Akhtar et al., ${ }^{31}$ have documented the antioxidant activity of Ficus species from Pakistan. In a study from Razagram Toormang Dir, KPK, Pakistan, the chemical test of aerial portion of Ficus sarmentosa plant showed presence of amino acids, anthraquinones, beta cyanin, cardiac glycoside, flavonoids, phlobatanins, reducing sugars, steroids, terpenoids, and tannins in methanol extracts and ethyl acetate fraction with antioxidant activity ${ }^{32}$. Ficus carica is another vital species of the Moraceae family commonly found in the temperate parts of the world. Leaves and fruits of this plant possess great antioxidant and antimicrobial potentials ${ }^{112}$. Samples of $F$. carica, collected from Bannu, Pakistan confirmed the presence of phytochemicals and antioxidant action assessed with DPPH assay revealed promising outcomes. Results corroborated that the methanol extract of $F$. carica fruit is good source of flavonoids, polyphenols, terpenoids, alkaloids and saponins with potential antioxidant activity. Fruit of this plant is also a worthy source of chromium iron, copper, selenium, manganese and zinc ${ }^{60}$. Fiscus microcarpaa from Islamabad, Pakistan has been scrutinized for the free radical scavenging activity of its aqueous and methanol/chloroform extracts. Extracts of this plant validated the presence of phenolics and flavonols with greater antioxidant activities due to antioxidant and reduction possessions ${ }^{31}$.

\section{Grewia asiatica L.}

Grewia asiatica belongs to the family Malvaceae. Species of the Malvaceae family are significant medicinally because of the presence of effective antioxidant compounds in their extracts including melvin, phenols and vitamins $A$ and $C^{35}$. Akhtar et al., ${ }^{31}$ pooled samples of G. asiatica from Mianwali, Pakistan and the antioxidant activity of its methanol/chloroform and aqueous extracts assessed ascertained significant antioxidant outcomes because of its wonderful reduction capacity. An investigation of methanol leaves extracts of $G$. asiatica from Multan, Pakistan evident the presence of phenolic contents. The antioxidant potential designated the leaves extracts of $G$. asiatica as beneficial assets with natural antioxidants ${ }^{24}$.

\section{Haloxylon griffithii}

Haloxylon griffithii plant belongs to the Chenopodiaceae family. It consists of $\sim 100$ genera with 1200 species $^{113}$. 
Baki et al., ${ }^{45}$ informed the antioxidant activity of $H$. griffithii from Balochistan, Pakistan. They determined the antioxidant potentials of methanol extracts of $\mathrm{H}$. griffithii spectro photometrically through the FRAP, DPPH and TAC of phosphor molybdenum assay. The values for DPPH assay of $H$. griffithii recorded were $95.03 \%$ at the concentration of $1.0 \mathrm{mg} / \mathrm{ml}$. Furthermore, the FRAP value of the $H$. griffithii extract of extract proved a high and persuasive antioxidant activity.

\section{Hippophae rhmnoides L. (Sea buckthorn)}

Hippophae rhmnoides is a bush species that belongs to the family Eleagneaceae. In Pakistan, Hippophae rhamnoides berries obtained from the Skardo district and their methanol extracts were scrutinized for potential antioxidant activity. The extract containing emulsions and polyphenol-rich plant-derived extracts from this plant have proved promising antioxidant possibilities ${ }^{102}$. Leaves samples of $H$. rhamnoides collected from Skardu, Pakistan were inspected for the antioxidant activity of their methanol, acetone, $n$-hexane, chloroform, aqueous, ethanol, ethyl acetate and extracts where methanolic extracts displayed the highest activity. The leaves extracts of $H$. rhamnoides exhibited improved dose-dependent antioxidant activity and thus designated as precious natural antioxidant 52 .

\section{Imperata cylindrica L.}

Imperata cylindrica belongs to the family Poaceae. It is also called cogon or thatch grass. It possesses antioxidant, anticancer, immunomodulatory and neuroprotective activities ${ }^{114}$. Investigations of Fatima et al., ${ }^{64}$ form Bahawalpur, Pakistan validated the ethanol and acetone extracts of $I$. cylindrica aerial parts with important phytochemicals having antioxidant activity. Secondary metabolites were confirmed with greater antioxidant action in acetone and ethanol extracts of $I$. cylindrical.

\section{Ixora coccinea L.}

Ixora coccinea belongs to the family Rubiaceae. This plant is a great source of essential compounds including flavonoids, alkaloids, steroids tannins and terpenoids ${ }^{115}$ which gives antioxidant, hepatoprotective, antimicrobial, anti-mitotic, antinociceptive, anti-inflammatory and cardiovascular activities ${ }^{116}$. Various researchers ${ }^{19,115,116}$ have acknowledged the antioxidant activity of this essential plant from Pakistan. In Karachi, Pakistan, the methanolic extracts, fractions and sub-fractions of I. coccinea were assessed for free radical scavenging activity based on DPPH assay. I. coccinea leaves methanol extracts showed greater antioxidant action among the tested extracts with values $I_{50}=0.00315 \pm 0.0001 \mathrm{mg} / \mathrm{Ml}$. Twenty-six pure chemical compounds were obtained after further purification of the active fractions of $I$. coccinea where 5-0-caffeoyl quinic acid was obtained from flower fraction showed better antioxidant activity with $\mathrm{IC}_{50}=0.0467 \pm 0.0018 \mathrm{mg} / \mathrm{ml}$ than standard antioxidants (BHT and ascorbic acid) ${ }^{19}$.

\section{Jasminum L. species}

Jasminum $L$. is from the Oleaceae family. About $\sim 28$ genera with $\sim 900$ species have been assigned to this family. The genus Jasminum contains $\sim 200$ species ${ }^{117}$. The methanol/chloroform and aqueous extracts of two Jasminum species like Jasminum Sambac (L.) Aiton and Jasminum officinale $L$. showed flavonols and phenolic compounds with antioxidant potencies because of the great antioxidant and reduction capacities ${ }^{31}$. Another Jasminum species, J. humile was collected from Abbottabad, Pakistan and assessed for total phenolic content, antioxidant activity, NO scavenging and antibacterial profile of its flower extracts ( $n$-hexane, $n$ butanol and ethyl acetate). These plant extracts have been designated with vital antioxidant action with better $I_{50}$ values. Furthermore, phenolic contents present in the extracts of $J$. humile flower with antioxidant activity are a natural asset to impede microbial growth and inhibition of oxidative degradation, particularly in the food industry ${ }^{148}$.

\section{Juglans regia}

Juglans regia is a member of Juglandaceae family. Its fruit used in the diet reduces the chances of coronary heart diseases ${ }^{118}$. Linoleic acid among the fatty acids is the most important one, followed by palmitic acid, stearic acid and oleic acid ${ }^{119}$. The antioxidant activity of $J$. regia from the Chitral valley of Pakistan was validated by Rahman

et al., ${ }^{49}$ where they confirmed that J. regia holds greater antioxidant potential. The DPPH scavenging possessions of methanol crude extract of $\mathrm{J}$. regia revealed activities of $72.98 \%$ at a concentration of $100 \mu \mathrm{g} / \mathrm{ml}$ and $95.42 \%$ at 
$500 \mu \mathrm{g} / \mathrm{ml}$ concentration. Nevertheless, the lowest activity of $90 \%$ at $100 \mu \mathrm{g} / \mathrm{ml}$ and highest activity of $98 \%$ at $500 \mu \mathrm{g} / \mathrm{ml}$ was presented by ascorbic acid.

\section{Justicia adhatoda L.}

Justicia adhatoda of the family Acanthaceae grows wild in India, Nepal and Pakistan ${ }^{120}$. It is commonly called Malabar nut or Vasaka with bitter taste and unpleasant smell ${ }^{121}$. The medicinal significance and antioxidant activity of $\mathrm{J}$. adhatoda from Pakistan have been reported by various researchers ${ }^{19,31,40,83}$. In a study from Soon Sakesar, Punjab, Pakistan, the phytochemical, antioxidant and antibacterial evaluation exposed a very good range of phenolic compounds in ethanol or methanol fruit andflower extracts of $J$. adhatoda. Antioxidant potential of fruit and flower extracts authenticated moderate to good ability to DPPH free radicals scavangeing, linoleic acid peroxidation inhibition with better antibacterial activity ${ }^{83}$. In vitro study from Islamabad, Pakistan also validated leaf extracts of J. adhatoda with total alkaloid, crude oil, dietary fiber, flavonoid, protein, phenols, saponins, tannins and essential and non-essential metal ions. The ethanol extract of $J$. adhaotda have been designated as a better antioxidant candidate than butanol, chloroform, methanol and water extracts ${ }^{40}$. Akhtar et al., ${ }^{31}$ collected sample of $J$. adhatoda from Islamabad, Pakistan and the antioxidant activity of aqueous and methanol/chloroform leaves extract demonstrated antioxidant potential due to its reduction capacity. Another study from Mardan, KPK, Pakistan focused on the pharmacological activities of Justicia adhatoda with antioxidant activity. The DPPH activities and concentration of fractions were proportional because when the concentration of fractions increases the percent scavenging activity also increases ${ }^{19}$.

\section{Lantana camara L.}

Lanata camara is a member of the Verbenaceae family. It is utilized as a traditional medicine in Pakistan and grows at in altitude of $1500 \mathrm{~m}^{58}$. In one study, a phytochemical, antibacterial and antioxidant evaluation from Soon Sakesar, Punjab Pakistan exposed a very good range of phenolic compounds in ethanol or methanol fruit and flower extract of $L$. camara. The flower and fruit extracts were authenticated to scavenge DPPH free radicals and inhibit linoleic acid peroxidation with better antibacterial activity ${ }^{83}$. In another inquiry from Karachi, Pakistan, the antioxidant activity of methanol extracts and its fractions with lantadene-A, lantanilic acid and oleanolic acid, from upper portion of $L$. camara have been endorsed with good DPPH activity. The methanolic extract, its aqueous, petroleum ether and ethyl acetate fractions possess active antioxidant agents. One pure compound (oleanolic acid) was authenticated better antioxidant activity in contrast to ascorbic acid 84 .

\section{Melia azedarach}

Melia azedarach is a deciduous tree from the Meliaceae mahogany family. An investigation from Faisalabad, Pakistan $M$. azedarach leaves, stem bark and fruit aqueous and methanol extracts showed total flavonoid and phenols. A greater linoleic inhibition capacity and DPPH scavenging activity for sun-dried methanol extracts as compared to ambient dried extracts has been acknowledged and substantiated the potent antioxidant activity

of M. azedarach ${ }^{59}$. Azadirachta indica (A. Juss.) is another significant species of the family Meliaceae. Methanol/chloroform and aqueous leaves extracts of this plant assessed from Mianwali Pakistan corroborated the presence of antioxidants like flavonols and phenolic compounds with great antioxidant possessions and reduction abilities ${ }^{31}$.

\section{Mentha L. species}

The genus Mentha L. is from the Lameaceae family. Species of this genus are commonly found in Central Asia, Europe, and non-tropical regions of Africa. Extracts from Mentha species are used against headache, cold, cough, indigestion and stomach cramps ${ }^{122}$.

Investigations of Andleeb et al.,57, Akhtar et al., ${ }^{31}$ and Waris et al., ${ }^{28}$ acknowledged the antioxidant action of Mentha species from Pakistan. Mentha longifolia is another vital species of the genus Mentha. The phytochemical analysis of whole plant acetonic extracts of M. longifolia leaves from Peshawar, Pakistan corroborated the presence of flavonoids, alkaloids, saponins, triterpenoids and steroids. Moreover, the greatest scavenging of free radicals (\%) of the acetonic extract of this plant measured was $59 \%$ at many concentrations $(100-500 \mu \mathrm{g} / \mathrm{ml})^{28}$. Mentha piperita is a crucial species of the Mentha genus. Its methanol/chloroform and aqueous extracts were 
assessed from Rawalpindi, Pakistan where presence of antioxidants like flavonols and phenolic compounds provided great antioxidant capabilities in the tested extracts due to reduction abilities ${ }^{31}$. A study on Mentha spicata plant, collected from Muzaffarabad, AJK Pakistan revealed that its Diethyl ether, chloroform, ethanol and methanol extracts from leaves possess significant antioxidant activity ${ }^{57}$.

\section{Momordica charantia (Bitter gourd)}

Momordica charantia is from the Cucurbitaceae plant family. It is cultivated and eaten as a vegetable worldwide ${ }^{123}$. A study from Lahore, Pakistan assessed the antioxidant activity of this significant plant which proven to be a potent antioxidant candidate. The flakes extract retain potent free radical scavenging action of $63.20 \%$ followed by seed with $33.05 \%$, DPPH \% inhibition at $2 \mathrm{mg} / \mathrm{ml}$ concentration related to BHT as a standard antioxidant ${ }^{48}$.

\section{Moringa oleifera L.}

Moringa oleifera is a member of Moringaceae family. M. oleifera leaves are rich in vitamins $A$ and $C^{124}$ and other phytochemicals like flavonoid pigments such as rhamnetin, kaempferol, isoquercitrin and kaempferitrin ${ }^{125}$. A lot of researchers $31,62,124$ have conveyed the phytochemical analysis and antioxidant potentials of this important plant from Pakistan. Akhtar et al., ${ }^{31}$ collected a sample of M. oleifera from Kundian, Mianwali, Pakistan and checked the antioxidant action of its aqueous and chloroform/methanol extracts. The antioxidant activity of M. oleifera extracts verified extraordinary antioxidant activities because of better reduction capacity. LEMO, a phytochemical extracted from the ethanol leaves extracts of M. oleifera in Faisalabad, Pakistan has been verified as a better stabilizer of butter at refrigeration temperature. LEMO attained from ethanol leaves extracts of $M$. oleifera to possess prospective antioxidant activity at a concentration of $600 \mathrm{ppm}$ and is convenient in retaining organoleptic features of butter in the course of storage ${ }^{62}$.

\section{Morus alba (White Mulberry)}

Morus alba is a member of the Moraceae family. M. alba is used as a traditional medicine against bronchitis, digestive disorder, headache, smallpox, scabies and ulcers etc. Several researchers $31,49,61$ have described the antioxidant efficacy of Morus species from different regions of Pakistan. A phytochemicals screening from Mardan, Pakistan confirmed the presence of flavonoids, alkaloids, reducing sugar, terpenoids and phloba-tannins in aqueous leaf extracts of $M$. alba ${ }^{61}$ which give antioxidant activity to this plant. Akhtar et al. ${ }^{31}$ studied the antioxidant activity of aqueous and methanol/chloroform extracts of Morus nigra collected from Islamabad, Pakistan. The tested extracts of this plant validated better antioxidant actions with great reduction capability. The DPPH activity of crude ethanolic extracts of $M$. alba from the Chitral valley of Pakistan showed acceptable antioxidant activity of crude ethanol extracts ${ }^{49}$.

\section{Nasturtium officinale (W. T. Aiton)}

Nasturtium officinale belongs to the family Brassicaceae. Its extracts contain phenolic compounds, mainly in $\beta$-carotene and flavonoids in $\mathrm{NOE}^{126}$. Studies of Akhtar et al., ${ }^{31}$, Khan et al.., ${ }^{128}$ and Bibi et al.. ${ }^{127}$ have documented the antioxidant activity of this plant from Pakistan. Akhtar et al., ${ }^{31}$ collected samples of $N$. officinalen from Salgira park Pakistan and scrutinized the methanol/chloroform and aqueous extracts for potential antioxidant activity. Their results confirmed phenols and flavonols in the extracts with potential antioxidant action. Bibi et al., ${ }^{127}$ acquired samples of $N$. officinale from Tanawal areas of Pakistan and found the maximum antioxidant activity of its methanol extracts. Wild plants of Pakistan were evaluated for nutritional, antioxidant and antimicrobial assessment including the $N$. officinale and its antioxidant activity was authenticated in correlation with the presence of phenolic compounds ${ }^{128}$. From the North KPK region of Pakistan, the

$N$. officinale ethanol crude extracts and fractions were tested to check antioxidant action with DPPH assay. Their results validated ethanol crude extract with an acceptable range of antioxidant activity 38 .

\section{Origanum species}

Origanum is a member of the Lamiaceae family with $\sim 38$ shrubby, perennial and annual plants species. The majority of species of this genus are native to East Asia, Europe, North Africa and the Mediterranean area ${ }^{129}$. In a study ${ }^{58}$ from Faisalabad, Pakistan determine 39 and 43 components from two Origanum species. The major constituents like a-terpineol, terpinene-4-ol, linalool, 
linalyl-acetate and limonene have been documented from O. majorana extract; however, a-terpineol, carvacrol, thymol and o-cymene have been validated in 0 . vulgare extract. The resazurin microtitre and disc diffusion assays corroborated 0 . majorana extract with better antibacterial activity than 0 . vulgare extract against bacteria. The revelations of DPPH assay displayed 0 . vulgare extract with better activity than 0. majorana extract and both inhibited better oxidation of linoleic acid. Nevertheless, in another assay (bleaching $\beta$-carotene) 0 . vulgare extract substantiated improved antioxidant action as compared to O. majorana extract 58 .

\section{Oryza sativa L. (Rice bran)}

It belongs to the family Poaceae. Rice bran comprises 100 different antioxidants including oryzanol, tocotrienol and tocopherol. Studies of Iqbal et al., ${ }^{65}$, Anwar et al.,66 and Zubair et al., ${ }^{67}$ documented the antioxidant activity of Oryza sativa from Pakistan. The antioxidant potential of methanol extracts of indigenous varieties of rice bran was evaluated from Gujranwala, Pakistan. The presence of phenolic compounds with strong antioxidant activity was observed. Rice Bran Variety (RB-kr) displayed the longest growth period with remarkable antioxidant activity ${ }^{65}$. Another assessment from Karachi, Pakistan revealed the antioxidant action of rice bran methanol extracts. Higher activity among the rice bran extracts was authenticated. Moreover, the activity of some extracts in substrate oils stabilization under ambient was significantly different during storage ${ }^{66}$. From Kalashahkako Lahore, Pakistan, 10 different varieties of rice screened with orbital shaker technique and the effect of pure and aqueous ethanol, methanol and isopropanol on phenolics was evaluated with antioxidant activity. The aqueous methanol and aqueous isopropanol as an effective solvent promoted higher content of total phenolics and a remarkable antioxidant activity through DPPH assay, ferrous ionchelating activity and reducing power, particularly in three rice varieties ${ }^{67}$.

\section{Pentanema vestitum $\mathrm{L}$.}

Pentanema vestitum is a plant from Asteraceae family and sub family Inuleae ${ }^{130}$. The antioxidant activity of whole plant methanolic extracts of $P$. vestitum from Malakand Division Khyber Pukhukhwa, Pakistan on the basis of DPPH assay was acknowledged ${ }^{29}$. A non- significant difference in the inhibition percent at different concentrations of methanol extracts of $P$. vestitum and ascorbic acid at $P<0.05$ with $I C_{50}$ value of $13.00 \mathrm{ppm}$ in $P$. vestitum and 15.09ppm of ascorbic acid demonstrated potential antioxidant efficiency of this plant 29 .

\section{Periploca aphylla}

Periploca aphylla belongs to the family Asclepiadaceae. $P$. aphylla is medicinally employed for the treatment of swellings and tumors and its bark is specifically used in contradiction of fever ${ }^{131}$. Rauf et al., ${ }^{32}$ acknowledged antioxidant potential of $P$. aphylla from Razagram, Toormang, Dir Khyber Pakhtunkhwa, Pakistan, where the photochemical of screening of aerial part of $P$. aphylla revealed the presence of amino acid, beta cyanin, flavonoids, cardiac glycoside, comurrine, steroids, terpenoids and tannins. The DPPH assay validated methanol extracts and fraction of ethyl acetate of $P$. aphylla with significant scavenging activity among the entire fractions ${ }^{32}$.

\section{Pistacia integerrima (Stew.)}

Pistacia integerrima is a tree from Anacardiaceae family. It possesses promising biological activities like antioxidant, antimicrobial and hepatoprotective activities ${ }^{132}$. Ilahi et al., ${ }^{29}$ documented the antioxidant potential of $P$. integerrima from Malakand Division, Khyber Pukhukhwa, Pakistan, based on DPPH assay. Methanol extract from fruit of $P$. integerrima corroborated considerably maximum activity at different concentrations with $\mathrm{IC}_{50}$ value of $5.75 \mathrm{ppm}$ for $P$. integerrima and 15.09ppm for ascorbic acid.

\section{Poa annua L.}

Poa annua belongs to the Poaceae family. $P$. annua is cosmopolitan annual bluegrass with high phenotypic and genotypic variations. In Pakistan, an inquiry from Bahawalpur, appraised the aerial parts of $P$. annua plants with acetone and ethanol for the presence of phytochemical and antioxidant activity. Secondary metabolites in majority of plant extracts has been recorded with minimum ABTS, DPPH, NBT and reducing power assay in ethanol and acetone extracts of P. annua ${ }^{64}$. 


\section{Psidium guajava (Guava)}

Psidium guajava belongs to the Myrtaceae family. $P$. guajava is utilized as a remedy to treat skin problems and healing wounds ${ }^{133}$. In Pakistan, Wadood et al., ${ }^{61}$ and Rahman et al.,49 documented the presence of phytochemicals and assessed potential antioxidant activity of this plant. A study from the Chitral valley of Pakistan revealed DPPH scavenging possessions of $P$. guajava crude ethanolic extract. The maximum inhibition percent for the ethanol extracts noticed was $12.28 \%$ at a concentration of $500 \mu \mathrm{g} / \mathrm{ml}$ and minimum was $4.91 \%$ at $100 \mu \mathrm{g} / \mathrm{ml}$. On the other hand, minimum activity of $90 \%$ at $100 \mu \mathrm{g} / \mathrm{ml}$ concentrations and maximum activity of $98 \%$ at $500 \mu \mathrm{g} / \mathrm{ml}$ concentration of ascorbic acid was recorded ${ }^{49}$. A similar study from Mardan, Pakistan reported phytochemical constituents like alkaloids terpenoids, flavonoids, phlobatannins and reducing sugars in the aqueous extracts of $P$. guajava leaves ${ }^{61}$ that gives potential antioxidant action.

\section{Pteridium aquilinum}

Pteridium aquilinum belongs to Dennstaedtiaceae amily and utilized as wild vegetable in few countries of the world. It is employed as a traditional medicine contrary to headache, high fever and rheumatism ${ }^{126}$. From North Khyber Pakhtunkhwa, Pakistan, the crude ethanolic extracts and various fractions of $P$. aquilinum were evaluated for antioxidant action with DPPH assay that revealed crude ethanol extract with a remarkable highest range $(93.97 \%)$ of antioxidant activity 38 .

\section{Quercus incana (Roxb.)}

Quercus incana plant is from the Fagaceae family. This family is characterized by 8 genera containing $~ 900$ plant species distributed in world temperate region. In Pakistan, species of two genera like Castana and Quercus represents this family. Six wild species of the genus Quercus are distributed in the northern Pakistann ${ }^{54}$. An inquiry from Abbottabad district of Pakistan examined Q. incana extracts for their potential antioxidant activity along with antimicrobial activity. The $n$-butanol fraction of this plant is considered as relatively good option for antioxidant activity with great $\mathrm{IC}_{50}$ value $(55.4+$ $0.21 \mu \mathrm{g} / \mathrm{ml})$. The ethyl acetate fraction has NO scavenging activity $\left(\mathrm{IC}_{50}=23.21+0.31 \mu \mathrm{g} / \mathrm{ml}\right)$ and is considered to be fairly good than other fractions. Moreover, $Q$. incana extracts ( $n$-butanol) possess substantial antifungal and antibacterial actions against certain microorganism ${ }^{54}$. Likewise, the antioxidant activity of a compound (quercuschin) extracted from ethyl acetate fraction of $Q$. incana bark holds a remarkable antioxidant activity $(51.2 \mu \mathrm{g} / 10 \mu \mathrm{l})$ as compared to standard butylated hydroxyanisole $(45.9 \mu \mathrm{g} / 10 \mu \mathrm{l}))^{55}$.

\section{Rosa indica L.}

Rose is from the genus Rosa of the Rosacea family. Species of the Rosa genus holds promising phytochemicals with biological activities ${ }^{73}$. Investigations of Akhtar et al., ${ }^{31}$, Khurshid et al.., ${ }^{74}$ and Zahid et al.,73 recognized the antioxidant activity of species of Rosa from Pakistan. In a study from Islamabad, Pakistan, the presence of phenolic compounds with antioxidant activity of the methanol/chloroform and aqueous extracts of Rosa indica validated antioxidant and reduction capacities ${ }^{31}$. In Rawalakot AJK, Pakistan, the antioxidant activities of Rosa species aqueous extracts revealed inhibition against lipid peroxidation, in mice liver homogenate induced by prooxidants. Extracts of Rosa species validated high antioxidant and metal chelating activities in the phosphomolybdenum assay. It has been corroborated that the presence of extraordinary contents of favonoids and phenolics in aqueous extracts gives antioxidant potential to Rosa species ${ }^{74}$. In the ethanol leaves extracts of Rosa indica varieties, the presence of phytochemicals with potential antioxidant activity was confirmed. $R$. indica var cardinal red variety contains highest TPC (gallic acid) and TFC (quercetin) in its leaves extracts. Additionally, the phytochemicals present in the ethanol leaves extracts of $R$. indica var pink have highest percentage inhibition potency against free radicals ${ }^{73}$.

\section{Saccharum spontaneum $L$.}

Saccharum spontaneum is a member of the family Poaceae. A. spontaneum has a folk traditional medicinal uses against abdominal disorders, anaemia, obesity and vomiting. Roots of this plant are employed as diuretic, astringent, tonic, emollient and utilized against burning sensation, dyspepsia, respiratory ailments and piles ${ }^{134}$. In an inquiry form Bahawalpur, Pakistan, the aerial parts of S. spontaneum plants extracted with ethanol and aceton has been screened for phytochemicals and evaluated for antioxidant activity. Phytochemicals inquiry corroborated 
that secondary metabolites are present in the extracts of plant with high DPPH, ABTS, NBT activity and reducing power in ethanol and acetone extracts of S. spontaneum ${ }^{64}$.

\section{Solanum nigrum $\mathrm{L}$.}

Solanum is a prevalent genus of the Solanaceae family. In Pakistan, 15 species of Solanum are commonly found and 11 of them are acknowledged as medicinally important ${ }^{135}$. A crucial water insoluble steroidal alkaloid called solasodine is used to synthesize steroid drugs like corticosteroids ${ }^{136}$. Solanum nigrum, an important species encompasses many important compounds like essential oils in different parts ${ }^{137}$. In Mirpur Bhimber, Pakistan, Mazher et al., 80 unveiled the phytochemical profile of fruit, stem, and leaf extracts of $S$. nigrum prepared in distilled water, chloroform, ethanol and petroleum ether. Phytochemicals like alkaloids, flavonoids, saponins, steroids, tannins, terpenoids were observed in fruits extracts of $S$. nigrum. In Bahawalpur, Pakistan, the antioxidant activity of the fruits and leaves ethanolic extracts of $S$. nigrum with DPPH assay validated improved percentage of antioxidant activity. Hence, it could be substantiated that $S$. nigrum is a potential source of antioxidants ${ }^{79}$.

\section{Stellaria media L.}

Stellaria media of the family Caryophyllaceae is a small shrub with $20-30 \mathrm{~cm}$ height. $S$. media is employed against inflammation, kidney problems, wounds, rheumatic joints and ulcers. S. media is also against bronchitis, skin diseases, rheumatic pains and period pain ${ }^{138}$. Study of Usman et al. ${ }^{38}$ from North Khyber Pakhtunkhwa, Pakistan evaluated the crude ethanolic extracts and various fractions of $S$. media for potential antioxidant activity with DPPH assay. It has been revealed that the ethanol crude extracts of $S$. media possess an acceptable range of antioxidant activity.

\section{Swertia chirata (Roxb.)}

Swertia chirata is a member of the Gentianaceae family. It is being employed as anthelmintic, antipyretic ${ }^{139}$ and used for the treatment arthritis ${ }^{140}$. It is also used for disorders assossiated with urogenital or gastrointestinal tract disorders ${ }^{139}$ and for the treatment of cancer ${ }^{141}$. In a study from Galyat region of KPK, Pakistan, methanolic extract fractions of Swertia chirata aerial parts confirmed flavonoid and phenolic compounds with significantly high DPPH scavenging action. Moreover, these fractions have active antileishmanial and antimicrobial activity ${ }^{56}$.

\section{Terminalia arjuna $\mathrm{L}$.}

Terminalia arjuna from the family Combretaceae is commonly called as Arjuna. It is an extraordinary tree for having significant phytochemicals in its extracts ${ }^{142}$. In an inquiry from Faisalabad, Pakistan, the antioxidant activity of stem bark and leaves extracts of $T$. arjuna with aqueous methanol and ethanol were evaluated. The $T$. arjuna extracts contained considerable amount of total flavonoids as catechin and total phenolics as gallic acid equivalent. $T$. arjuna extracts also possesses a good DPPH activity with $\mathrm{IC}_{50}$ values of $2.71-7.68 \mu \mathrm{g} / \mathrm{ml}$. $T$. arjuna extracts also showed inhibition of lipid peroxidation (64.79-71.43\%) and reducing power (0.001$1.584 \mathrm{mg} / \mathrm{ml})^{47}$.

\section{Trifolium repens}

Trifolium repens is a member of the family Leguminosae. There are 103 species commonly found in Turkey. Trakya having 67 Trifolium taxa and is a centre of diversity ${ }^{143}$. In North Khyber Pakhtunkhwa, Pakistan, the crude ethanolic extracts and various fractions of $T$. repens were evaluated for antioxidant action with DPPH assay that revealed crude ethanol extract with an acceptable range of antioxidant activity 38 .

\section{Typha domigensis (Pers.)}

Typha domigensis is a member of the Typhaceae family. Pollen grains of Typha genus are utilized in diet to cure fever and injuries and to prevent wound bleedings. Sardar et al., ${ }^{81}$ reported the inhibition of free radicals in various solvents with ABTS and DPPH radical scavenging assays from Pakistan. T. domigensis pollen extracts have better antioxidant action because of phenolic and flavonoid compounds which are are better candidates in the formulation of drugs against cancer and aging disorders.

\section{Urtica dioica (L.)}

Urtica dioica is a a plant species from the Urticaceae family. Leaf extracts of $U$. diocia are employed as an antihaemorrhagic to control nose bleedings and extreme menstrual flow. Roots of this plant are used against benign prostate hyperplasia. It is also utilized against rheumatic conditions and urinary tract disorders and 
allergies $^{144}$. The distribution of phytochemicals from the aerial parts ethanol extracts of $U$. diocia from Islamabad, Pakistan authenticated the presence of important flavonoids like orientin and luteolin ${ }^{82}$. In the North Khyber Pakhtunkhwa, Pakistan, the crude ethanolic extracts and various fractions of $U$. dioica screened for antioxidant potential using DPPH assay showed ethanol crude extract with superior antioxidant activity 38 .

\section{Vetiveria zizanioides (L.)}

Vetiveria zizanioides of the Poaceae family has thick adventitious roots. It is Vetiver grass traditionally used as stimulant and stomachic. It is used to treat inflammations and fevers. This grass has applications in perfume industry and also grown for oil production ${ }^{145}$. In an inquiry form Bahawalpur, Pakistan, the aerial parts of V. zizanioides evaluated for phytochemicals and antioxidant activity confirmed the secondary metabolites present in most of the plant extracts. The higher antioxidant activity with DPPH, NBT, ABTS and reducing power assay has also been documented in acetone and ethanol extracts of $V$. zizanioides ${ }^{64}$.

\section{Withna species}

Withna species belongs to the family Solanaceae. Species of the Withna genus have medicinal value and has been reported for their antioxidant and antihyperglycemic activity ${ }^{146}$. In Pakistan, the antioxidant activity of two vital species of the Withna genus namely W. somnifera ${ }^{29,79}$ and $W$. coagulans ${ }^{29,31}$ have been reported. In a study from Malakand Division of KPK, Pakistan, llahi et al., ${ }^{29}$, estimated antioxidant action of W. somniferra with DPPH assay. The percent inhibition $\left(\mathrm{IC}_{50}=46.85 \mathrm{ppm}\right)$ caused by methanolic extract W. somniferra fruits was worth noticing with great antioxidant potential. Akhter et al., ${ }^{31}$ collected samples of W. coagulans from Mianwali, Pakistan and assessed the antioxidant activity of aqueous and methanol/chloroform extracts. The tested extracts validated promising antioxidant actions due to its total antioxidant and reduction dimensions. In an inquiry from Bahawalpur, Pakistan, the antioxidant activity with DPPH assay corroborated enhanced percentage of antioxidant activity in the ethanol leaves and fruit extracts of $W$. somnifera ${ }^{79}$.

\section{Zea mays (Corn)}

Zea mays belong to the family Poaceae. Its extracts contain steroids, alkaloids and flavonoids which are significant source of natural antioxidants. Phenolic compounds can also be extracted from corn silk extract of Zea mays and these constituents possess great antioxidant activity in nature ${ }^{147}$. Various researchers ${ }^{68,69,70}$ documented the antioxidant potential of $Z$. mays from Pakistan. An inquiry on corn silk from Multan, Pakistan showed worthy phytochemical composition with a robust antioxidant activity. A polarity dependent rise in extracts yield, free radical scavenging action and phytochemical content of extracts reinforced with regression analysis of experimental data68. Z. mays seeds collected from Sahiwal, Pakistan were screened for phytochemicals that showed coumarins, saponins, alkaloids, terpenoids and tannins. An increased TPC under lead stress and greater scavenging rate of maize seeds methanol extract sanctioned maize extracts with potential antioxidant activity ${ }^{69}$. A study from Faisalabad, Pakistan exposed three varieties of $Z$. mays including Golden, Sultan and Agatti: 85 containing phenolic compounds with effective inhibition in the oxidation process present in its ear tissues extracts. Maize hinders the oxidation reaction and decreases diabetes mellitus complications. The total phenolics content, SOD, peroxidase and catalase are the indicators for higher antioxidant activity in decreasing obstructions in diabetic patients ${ }^{70}$.

\section{Ziziphus jujube (Mill.)}

Ziziphus jujube belongs to the family Rhamnaceae. It contains simple carbohydrates (9\%), protein $(2 \%)$ and polysaccharides $(2 \%)^{144}$. Investigations of Rasool et al., ${ }^{149}$, Shad et al., ${ }^{60}$ and Rahman et al., ${ }^{49}$ validated antioxidant activity of species of $Z$. jujube from Pakistan. The DPPH assay of crude ethanolic extract of this plant examined from Chitral valley of Pakistan exposed better antioxidant activity of $19.52 \%$ at concentration of $500 \mu \mathrm{g} / \mathrm{ml}$ and $2.00 \%$ at $100 \mu \mathrm{g} / \mathrm{ml}$ concentration). Lowest activity of $90 \%$ at concentration of $100 \mu \mathrm{g} / \mathrm{ml}$ and maximum activity of $98 \%$ at $500 \mu \mathrm{g} / \mathrm{ml}$ concentration was showed by ascorbic acid ${ }^{49}$. A study from Kohat, Pakistan corroborated that the methanol extracts of fruit of $Z$. jujube are good source of alkaloids, flavonoids, polyphenols, terpenoids and saponins. Fruit of this plant has shown to 
be a good source of copper, iron, chromium, selenium, manganese and zinc. The phytochemicals present are potential source of antioxidant agents ${ }^{60}$. In Faisalabad, Pakistan, the antioxidant effectiveness of $Z$. jujube showed the total flavonoid and phenolic contents in shoot extracts substantiated good DPPH inhibition $\left(\mathrm{IC}_{50}\right)$ and inhibition of linoleic acid peroxidation. Methanolic extract and chloroform fraction of the Z. jujuba shoots extracts have shown with highest antioxidant activity ${ }^{149}$.

\section{CONCLUSION}

Since the last decade, phytochemical investigations with potential antioxidant action of plant extracts from different families have got substantial consideration. Antioxidants from plants origin, with free radical scavenging activity, have great applicability in the treatment and prevention of health-related complications caused by free radicals. Asteracea, Poaceae and Rutaceae are the prominent plant families whose species are maximally scrutinized for their potential antioxidant activity from Pakistan. The present review clearly designates that the presence of phytochemicals and antioxidant profile of medicinal plants from Pakistan vary with the species of the plants and material/extracts used. Consequently, this review determines the pharmacological significance of these plants which will be advantageous to discover further plant based chemicals for drug development with fewer side effects.

\section{LIST OF ABBREVIATIONS}

ABTS Azinobis-3-ethylbenzothiazoline-6-sulfonate

DMPD Dimethyl-p-phenylene diamine dihydrochloride

DPPH 2,2-Diphenyl, 1-picrylhydrazyl hydrate

FRAP Ferric reducing antioxidant power

HPLC High performance liquid chromatography

LPO Lipid peroxidation

TAC Total antioxidant capacity

TEAC Trolox equivalent antioxidant capacity

TPC Total phenolic content

TFC Total flavonoid content

\section{REFERENCES}

1. Lai LS, Chou ST, Chao WW. Studies on the antioxidative activities of Hsian-tsao (Mesona procumbens Hemsl) leaf gum. J Agric Food Chem. 2001; 49:963-8.

2. Huang $\mathrm{D}, \mathrm{Ou} B$, Prior RL. The chemistry behind antioxidant capacity assays. J Agric Food Chem. 2005; 53:1841-56.

3. Lewis WH, Elvin-Lewis MP. Medicinal plants as a source of new therapeutics. Ann Miss Bot Gard 1995; 82:16-24.

4. Liu RH. Health benefits of fruit and vegetables are from additive and Synergistic combinations of phytochemicals. Amer. J. Clin. Nut. 2003; 78: 517-20.

5. Jayaprakasha GK, Girennavar B, Patil BS. Antioxidant capacity of pummelo and navel oranges: Extraction efficiency of solvents in sequence. LWT Food Sci Tech. 2008; 41(3):376-84.

6. Parr AJ, Bolwell GP. Phenols in the plant and in man. The potential for possible nutritional enhancement of the diet by modifying the phenols content or profile. $J$ Sci Food Agricul 2000; 80:985-1012.

7. Alghazeer R, Gao H, Howell NK. Cytotoxicity of oxidised lipids in cultured colonal human intestinal cancer cells (caco-2 cells). Toxicol Lett. 2008; 180:202-11.

8. Ferreira D, Stade D. Oligomeric proanthocyanidins: Naturally occurring O-heterocycles. Nat Prod Res. 2002; 19:517-41.

9. Hamayun M, Khan SA, Iqbal I, Rehman G, Hayat T. Ethnobotanical profile of Utror and Gabral valleys, district Swat, Pakistan. Ethnobot Leafl. 2005; 1:9-15.

10. Rizvi MA. Elemental composition of medicinal flowers. Pak J Bot. 2007; 39:2541-52.

11. Gurib-Fakim A. medicinal plants: Traditions of yesterday and drugs of tomorrow. Mol Asp Med. 2006; 27:1-93.

12. Ullah $S$, Khan MR, Shah NA, Shah SA, Majid M, Farooq MA. Ethnomedicinal plant use value in the Lakki Marwat District of Pakistan. J Ethnopharmacol. 2014; 158:412-22.

13. Shukla S, Mehta A, Mehta P, Vyas SP, Shukla S, Bajpai VK. Studies on anti-inflammatory, antipyretic and analgesic properties of Caesalpinia bonducella F. seed oil in experimental animal models. Food Chem Toxicol. 2010. 48:61-4.

14. Imran I, Haq MZU, Calani L, Mazzeo T, Pellegrini N. Phenolic profile and antioxidant potential of selected 
plants of Pakistan. J Appl Bot Food Qual. 2014; 87:30-5.

15. Ghauri AO, Ahmad S, Rehman T, Abbasi WM, Bilal $M$, Arshad A. Screening of biological activities of some Leguminosae (Fabaceae) family plants. RADS J Pharma Sci. 2018; 6:132-7.

16. Omino EA, Kokwaro JO. Ethnobotany of Apocynaceae species in Kenya. J Ethnopharmacol.1993; 40:167-80.

17. Magassouba FB, Dillo A, Kouyate M, Mara F, Bangoura O, Camara A, et al. Ethnobotanical survey and antibacterial activity of some plants used in Guinean traditional medicine. J. Ethnopharmacol. 2007; 114:44-53.

18. Ahmed SK, Versiani MA, Ikram A, Sattar SA, Faizi S. Cytotoxic cardiac glycosides from the fruits (pods) of Adenium Obesum (Forssk.) Roem. \& Schult. Nat Prod Res. 2017; 31:1205-8.

19. Khatoon A, Versiani MA, Shamshad S, Sattar SA, Khan $\mathrm{H}$, Ikram $\mathrm{A}$, et al. Antioxidant properties and phytochemical principles of some medicinal plants: Adenium obesum (Forssk.) Roem. \& Schult., Ixora coccinea Linn. and Aegle marmelos Linn. FUUAST J Biol. 2018; 8:49-58.

20. Chakthong $S$, Weaaryee $P$, Puangphtet $P$, Mahabusarakam W, Plodpai P. Alkaloid and coumarins from the green fruits of Aegle marmelos. Phytochem. 2012; 75:108-13.

21. Dhankar S, Ruhil S, Balhara M, Dhankar S. Aegle marmelos (Linn.) Correa: A potential source of phytomedicine. J Med PI Res. 2011; 5:1497-1507.

22. Rahman A, Imran $H$, Iqbal L, Taqvi SIH, Fatima N, Yaqeen Z. Dry and ripe fruit of Aegle marmelos L: A potent source of antioxidant, lipoxygenase inhibitors and free radical scavenger. Pak J Pharm Sci. 2013; 29:1127-31.

23. Burkil HM. The useful plants of West Tropical Africa. Royal botanic gardens, Kew. London. 2000; pp:11-13.

24. Imran I, Haq MZU, Calani L, Mazzeo T, Pellegrini N. Phenolic profile and antioxidant potential of selected plants of Pakistan. J Appl Bot Food Qual. 2014; 87:30-5.

25. Haq MZU, Ahmad S, Qayum M, Ercişli $S$. Compositional studies and antioxidant potential of Albizia lebbeck (L.) Benth. pods and seeds. Turk J Biol. 2013; 37:25-32.

26. Park YI, Jo TH. Perspective of industrial application of Aloe vera. In: New Perspective on Aloe. (Eds.): Y.I. Park and S.K. Lee. Springer Verlag, New York, USA. 2006; pp:191-200.
27. Malik NZ, Riaz M, Noshad QQ, Rashid N, Ain QU, Hussain A. Morphological, phytochemical and antifungal analysis of Aloe vera $\mathrm{L}$. leaf extracts. Asian J Agric Biol 2017; 5:177-87.

28. Waris $Z$, Iqbal $Y$, Hussain $A$, Shafqatullah, Khan $A A$, Ali A, Khan MW. Proximate composition, phytochemical analysis and antioxidant capacity of Aloe vera, Cannabis sativa and Mentha Iongifolia. Pure Appl Biol. 2018; 7:1122-30.

29. Ilahi I, Samar S, Khan I, Ahmad I. In vitro antioxidant activities of four medicinal plants on the basis of DPPH free radical scavenging. Pak J Pharma Sci. 2013; 26:949-52.

30. Raza SA, Rashid A, William J, Arshed SF, Arshad M. Comparison of antioxidant activity of some medicinally important plants from Pakistan. Acta Scient Polon Technol Aliment. 2013; 12:403-10.

31. Akhtar N, Haq IU, Mirza B. Phytochemical analysis and comprehensive evaluation of antimicrobial and antioxidant properties of 61 medicinal plant species. Arab J Chem. 2015; 11:1223-35.

32. Rauf A, Uddin G, Ali M, Ahmad N, Gul S. Phytochemical screening and antioxidant activity of Pakistani medicinal plants. Wudpeck. J Med PI. 2013; 2:001-6.

33. Iqbal S, Younas U, Chan KW, Haq MZU, Ismail M. Chemical composition of Artemisia annua L. leaves and antioxidant potential of extracts as a function of extraction solvents. Mol. 2012; 17:6020-32.

34. Ashraf A, Sarfraz RA, Mahmood A. Phenolic compounds' characterization of Artemisia rutifolia spreng from Pakistani flora and their relationships with antioxidant and antimicrobial attributes. Int $\mathrm{J}$ Food Prop. 2017; 20:2538-49.

35. Khan MR, Raza SA, Arshad M, Ch AR, Razzaq A. Antioxidant potential of indigenous medicinal plants of district Gujrat Pakistan. J Pharm Sci Technol. 2014; 4:21-2.

36. Ahmed S, Shakeel F. Voltammetric determination of antioxidant character in Berberis lycium Royel, Zanthoxylum armatum and Morus nigra Linn plants. Pak J Pharm Sci. 2012; 25:501-7.

37. Sabir S, Tahir K, Rashid N, Naz S, Masood B, Shah MA, Sualeh M. Phytochemical and antioxidant studies of Berberis lycium. Pak J Pharm Sci. 2013; 26:116572.

38. Usman R, Khan A, Gul S, Rauf A, Muhammad N. Preliminary antioxidant profile of selected medicinal plants of Pakistan. Mid East J Med PI. Res. 2012; 1:24-7. 
39. Bibi F, Ahmad H, Qureshi RA, Shaheen N, Tabbasum $S$, Mulk $S$, et al. Ethno medicinal attributes and antioxidant screening of some selected plant species of Tanawal area, Pakistan. Int J Biosci. 2016; 9:23754.

40. Rasheed F, Kayani WK, Mahmood A, Gulfraz M. Detection of bioactive fractions of Justicia adhatoda L. leaves. Canad. J Appl Sci. 2013; 3:1-17.

41. Rashid F, Butt FA, Nasreen S, Nisa FU, Kanwal Z, Kaleem $A$, et al. In vitro antimicrobial and antioxidant activities of two medicinal plants against some clinically important bacteria. FUUAST J Biol. 2016; 6:103-7.

42. Ullah S, Jan G, Gul F, Khan S, Husna H, Sher J, et al. Phytochemistry and antibacterial activities of some selected plants of war affected area of Bajaur agency, Pakistan. J Pharmacog Phytochem. 2018; 7:415-22.

43. Haq MZU, Ćavar S, Qayum M, Imran I, de Feo V. Compositional studies: Antioxidant and antidiabetic activities of Capparis decidua (Forsk.) Edgew. Int J Mol Sci. 2011; 12:8846-61.

44. Ajaib M, Hussain T, Farooq S, Ashiq M. Analysis of antimicrobial and antioxidant activities of Chenopodium ambrosioides: An ethnomedicinal plant. J Chem. 2016; 1-11.

45. Baqi A, Samiullah, Tareen RB, Mengal A, Khan N, Behlil $F$, et al. Determination of antioxidants in two medicinally important plants, Haloxylon griffithii and Convolvulus leiocalycinus, of Balochistan. Pure Appl Biol. 2018; 7:296-308.

46. Saadullah M, Chaudary BA, Uzair M. Antioxidant, phytotoxic and antiurease activities, and total phenolic and flavonoid contents of Conocarpus lancifolius (Combretaceae). Trop J Pharm Res. 2016; 15:55561.

47. Chatha SAS, Hussain Al, Asad R, Majeed M, Aslam $\mathrm{N}$. Bioactive components and antioxidant eroperties of Terminalia arjuna L. Extracts. J Food Proc Technol. 2014; 5:298-305.

48. Saeed MK, Shahzadi I, Ahmad I, Ahmad R, Shahzad K, Ashraf M, Nisa VU. Nutritional analysis and antioxidant activity of bitter gourd (Momordica charantia) from Pakistan. Pharmacol Online. 2010; 1:252-60.

49. Rahman TU, Khan T, Khattak KF, Ali A, Liaqat W, Zeb MA. Antioxidant activity of selected medicinal plants of Pakistan. Biochem Physiol. 2016; 5:208-15.

50. Khattak KF. Free radical scavenging activity, phytochemical composition and nutrient analysis of
Elaeagnus umbellata berry. J Med PI Res. 2012; 6:5196-203.

51. Khan BA, Akhtar N, Khan H, Braga VDA. Development, characterization and antioxidant activity of polysorbate based O/W emulsion containing polyphenols derived from Hippophae rhamnoides and Cassia fistula. Braz. J Pharm Sci. 2013; 49:763-74.

52. Ali J, Ahmad B. Evaluation of antioxidant activities of Hippophae rhamnoides Linn. leaves extracts. J Coast Life Med. 2015; 3:379-81.

53. Haq MZU, Iqbal S, Ahmad S, Bhangr MI, Wiczkowski W, Amarowicz R. Antioxidant potential of desi chickpea varieties commonly consumed in Pakistan. J Food Lip. 2008; 15:326-42.

54. Sarwar R, Farooq U, Khan A, Naz S, Khan S, Khan A, Rauf $A$, Bahadar $H$, Uddin $R$ et al. Evaluation of antioxidant, free radical scavenging, and antimicrobial activity of Quercus incana Roxb. Front Pharmacol. 2015; 6:277-83.

55. Gul F, Khan KM, Adhikari A, Zafar S, Akram M, Khan $\mathrm{H}$, et al. Antimicrobial and antioxidant activities of a new metabolite from Quercus incana. Nat Prod Res. 2017; 31:1901-9.

56. Khan I, Ahmad B, Azam S, Hassan F, Nazish, Aziz A, et al. Pharmacological activities of Justicia adhatoda. Pak J Pharm Sci. 2018; 31:371-7.

57. Andleeb S, Tahir M, Khalid M, Awan UA, Riaz N, Ali S. Antibacterial and antioxidant activities of traditional herbs and honey against fish associated bacterial pathogens. Pak J Zool. 2014; 46:933-40.

58. Hussain Al, Anwar F, Rasheed S, Nigam PS, Janneh $O$, Sarker SD. Composition, antioxidant and chemotherapeutic properties of the essential oils from two Origanum species growing in Pakistan. Braz J Pharmacog. 2011; 21:943-52.

59. Munir A, Sultana B, Babar T, Bashir A, Amjad M, Hassan QU. Investigation on the Antioxidant activity of leaves, fruit and stem bark of Dhraik (Melia azedarach). Europ J Appl Sci. 2012; 4:47-51.

60. Shad AA, Ahmad S, Ullah R, AbdEl-Salam NM, Fouad $\mathrm{H}$, Rehman NU, et al. Phytochemical and biological activities of four wild medicinal plants. Sci World J. 2014; 1-7.

61. Wadood A, Ghufran M, Jamal SB, Naeem M, Khan A, Ghaffar R, et al. Phytochemical analysis of medicinal plants occurring in local area of Mardan. Biochem Analy Biochem. 2013; 2:144-9.

62. Nadeem M, Abdullah M, Hussain I, Inayat S, Javid A, Zahoor Y. Antioxidant potential of Moringa oleifera leaf extract for the stabilisation of butter at 
refrigeration temperature. Czech J Food Sci. 2013; 31:332-9.

63. Zaman T, Syed MS, Isfaq S, Khan MS. Biological activities of stem, leaves and essential oil of Cedrus deodara from district Poonch, Rawalakot Azad Kashmir, Pakistan. Turk J Agric Food Sci Technol. 2018; 6:1114-9.

64. Fatima I, Kanwal S, Mahmood T. Evaluation of biological potential of selected species of family Poaceae from Bahawalpur, Pakistan. BMC Compl Alt Med. 2018; 18:27-35.

65. Iqbal S, Bhanger MI, Anwar F. Antioxidant properties and components of some commercially available varieties of rice bran in Pakistan. Food Chem. 2005; 93: 265-72.

66. Anwar F, Jamil A, lqbal S, Sheikh MA. Antioxidant activity of various plant extracts under ambient and accelerated storage of sunflower oil. Grasas Y Aceit. 2006; 57:189-97.

67. Zubair M, Anwar F, Shahid SA. Effect of extraction solvents on phenolics and antioxidant activity of selected varieties of Pakistani rice (Oryza sativa L.). Int J Agric Biol. 2012; 14:935-40.

68. Nawaz H, Aslam M, Muntaha ST. Effect of solvent polarity and extraction method on phytochemical composition and antioxidant potential of corn silk. Free Rad Antiox. 2019; 9:5-11.

69. Wattoo JI, Munawar S, Afzal M, Farooq A, Saleem MA. Biological activity and characterization of bioactive compounds under lead induced stress in Maize. Adv Life Sci. 2018; 5:96-103.

70. Shahzadi $H$, Sheikh MA, Hameed A, Jamil A, Rehman SU. Comparative antioxidant potential and bioactivity of maize (Zea mays) ear tissues from different genotypes. Int J Agric Biol. 2015; 17:539-46.

71. Rasool N, Rızwan K, Zubaır M, Naveed KR, Imran I, Ahmed VU. Antioxidant potential of different extracts and fractions of Catharanthus roseus shoots. Int $\mathrm{J}$ Phytomed. 2011; 3:108-14.

72. Rasheed M, Hussain I, Rafiq S, Hayat I, Qayyum A, Ishaq $S$, et al. Chemical composition and antioxidant activity of quince fruit pulp collected from different locations. Int J Food Process. 2018; 21:2320-7.

73. Zahid K, Ahmed M, Khan F. Phytochemical screening, antioxidant activity, total phenolic and total flavonoid contents of seven local varieties of Rosa indica L. Nat Prod Res. 2018; 32:1239-43.

74. Khurshid H, Sabir SM, Awan SI, Abbas SR, Irshad M. Antioxidant activities of aqueous extracts from nine different rose cultivars. Int J Food Stud. 2018; 7:6475.

75. Asjad HMM, Akhtar MS, Bashir S, Din B, Gulzar F, Khalid $\mathrm{R}$, et al. Phenol, flavonoid contents and antioxidant activity of six common Citrus plants in Pakistan. J Pharma Cosm Sci. 2013; 1:1-5.

76. Shah NA, Khan MR, Nigussie D. Phytochemical, antioxidant and anti-leishmania activity of selected Pakistani plants. Int J Clin Pharmacol Res. 2016; 1:555-8.

77. Ahmed M, Phul AR, Haq IU, Bibi G, Mazhar K, Rehman TU, et al. Antioxidant, anticancer and antibacterial potential of Zakhm-e-hayat rhizomes crude extract and fractions. Pak J Pharm Sci. 2016; 29:895-902.

78. Fatima H, Khan K, Zia M, Rehman TU, Mirza B, Haq IU. Extraction optimization of medicinally important metabolites from Datura innoxia Mill.: An in vitro biological and phytochemical investigation. BMC Compl Alt Med. 2015; 15:376-9.

79. Fatima I, Hussain T, Rafay M, Akram M, Bano S, Shabbir S. Evaluation of antioxidant activity of leaves and fruits extracts of five medicinal plants. Pak J Pharm Sci. 2017; 30: 1625-8.

80. Mazher M, Malik NZ, Riaz M, Hussain A, Ali Y, Noshad $Q Q$. Phytochemistry and antibacterial assay of fruit, leaf and stem extracts of Solanum nigrum $\mathrm{L}$. in different solvent. Int J Biosci. 2016; 9:129-36.

81. Sardar AA, Khan ZUD, Perveen A, Farid S, Khan IU. In vitro antioxidant potential and free radical scavenging activity of various extracts of pollen of Typha domigensis Pers. Pak J Pharm Sci. 2014; 27 : 279-84.

82. Khan AM, Qureshi RA, Ullah F, Shinwari ZK, Khan J. Flavonoids distribution in selected medicinal plants of Margalla hills and surroundings. Pak J Bot. 2012; 44: 1241-5.

83. Naqvi SAR, Waseem R, Mahmood N, Hussain Z, Khan ZA, Shahzad SA, et al. Phenolic acid content, antioxidant properties, and antibacterial potential of flowers and fruits from selected Pakistani indigenous medicinal plants. Sci Asia. 2013; 39:340-5.

84. Ayub A, Tauseef S, Ali ST, Begum S, Siddiqui BS, Ahmed A. Antioxidant activity of the medicinal plant Lantana camara L. FUUAST J Biol. 2017; 7:227-30.

85. Iqbal $P, A$ med $D$, Asghar MN. A comparative in vitro antioxidant potential profile of extracts from different parts of Fagonia cretica. Asian Pacif J Trop Med. 2014; 7:473-80. 
86. Terra DA, Amorim L, Catanho MTJ, Fonseca A, Santos-Filho SD, Brandão-Neto J, et al. Effect of an extract of Artemisia vulgaris L. (Mugwort) on the in vitro labeling of red blood cells and plasma proteins with technetium 99m. Braz Arc Biol Tech. 2007; 50:123-8.

87. Hussain A, Hayat MQ, Sahreen S, Ain QU, Bokhari SAl. Pharmacological promises of genus Artemisia (Asteraceae): A review. Proceed. Pak Acad Sci B. Life Environ Sci. 2017; 54:265-87.

88. Shan S, Huang X, Shah MH, Abbasi AM. Evaluation of polyphenolics content and antioxidant activity in edible wild fruits. BioMed Res Int. 2019; 1-11.

89. Islam MUI, Azhar I, Usmanghani K, Gill MA, Din SU, Ahmad A. Antifungal activity evaluation of Bergenia ciliata. Pak. J. Pharmacol. 2002; 19:1-6.

90. Hartsel JA, Eades J, Hickory B, Makriyannis A. Cannabis sativa and Hemp, Nutraceuticals: Efficacy, safety and toxicity. 2016; pp: 735-54.

91. Mukhtar M, Arshad M, Ahmad M, Pomerantz RJ, Wigdahl B, Parveen Z. Antiviral potentials of medicinal plants. Virus Res. 2008; 131:111-20.

92. Gupta RK. Medicinal and aromatic plants with colour plates-Traditional \& commercial uses, Agrotechniques, Biodiversity, Conservation, 1st ed.; CBS Publishers and Distributors Pvt. Ltd.: Dehli, India pp. 2010; 114-5.

93. Singh D, Rao S, Tripathi A. Cedar wood oil as a potential insecticidal agent against mosquitoes. Naturwissenschaften. 1984; 71:265-6.

94. Vikas S, Dhar K, Pooja S, Parul S. Indian herbal medicine-A natural cure to asthma. Int J Pharmacog Phytochem Res. 2013; 14: 302-10.

95. Zaman T, Syed MS, Isfaq S, Khan MS. Biological activities of stem, leaves and essential oil of Cedrus deodara from district Poonch, Rawalakot Azad Kashmir, Pakistan. Turk J Agric Food Sci Technol. 2018; 6:1114-9.

96. Schaneberg BT, Mikell JR, Bedir E, Khan IA. An improved HPLC method for quantitative determination of six triterpenes in Centella asiatica extracts and commercial products. Pharmazie. 2003; 58: 381-4.

97. Munir U, Perveen A, Qamarunnisa S. Comparative pharmacognostic evaluation of some species of the genera Suaeda and Salsola leaf (Chenopodiaceae). Pak J Pharm Sci. 2014; 27:1309-15.

98. Singh et al. Techniques of weed management in chickpea-A Review. Indian J Weed Sci. 2003; $35: 45-8$.
99. Khokhar SN, Khan MA, Chudhri MF. Some characters of Chickpea-Nodulating rhizobia native to that soil. Pak J Biol Sci. 2001; 4(8):1016-9.

100. Abbas ZK, Saggu S, Sakeran MI, Zidan N, Rehman $\mathrm{H}$, Ansari AA. Phytochemical, antioxidant and mineral composition of hydroalcoholic extract of chicory (Cichorium intybus L.) leaves. Saudi J Biol Sci. 2015; 22:322-6.

101. Mehmood M, Dar KK, Ali A, Awan UA, Nayyer AQ, Ghous $\mathrm{T}$, et al. In vitro assessment of antioxidant, antibacterial and phytochemical analysis of peel of Citrus sinensis. Pak J Pharm Sci. 2015; 28:231-9.

102. Khan MA, Shinwari MI, Niazi HA. Medicinal plants in the Pothwar region of Pakistan. Department of Biological Sciences. Quaid-i-Azam University, Islamabad, Pakistan. 2003; 1-8.

103. Riaz T, Abbasi MA, Shahzadi T, Rehman AU, Siddiqui SZ, Ajaib M. Colebrookia oppositifolia: A valuable source for natural antioxidants. J Med PI Res. 2001; 5:4180-7.

104. Abdel-Hameed ESS, Bazaid SA, Shohayeb MM, ElSayed MM, El-Wakil EA. Phytochemical studies and evaluation of antioxidant, anticancer and antimicrobial properties of Conocarpus erectus L. growing in Taif, Saudi Arabia. Europ J Med PI. 2012; 2:93-112.

105. Saadullah M, Chaudary BA, Uzair M. Antioxidant, phytotoxic and antiurease activities, and total phenolic and flavonoid contents of Conocarpus lancifolius (Combretaceae). Trop J Pharm Res. 2016; 15:55561.

106. Gheisari HR, Abhari KH. Drying method effect on the antioxidant of Quince (Cydonia oblonga) tea. Acta Sci Polon Technol Aliment. 2014; 13:129-34.

107. Veeresh KP, Rauf FB, Sulthana B, Kumar MS, Mangilal T. Evaluation of antimicrobial activity of ethanolic extract of Dactyloctenium aegyptium. Int J Pharm Res. 2015; 5:338-43.

108. Stevens RD, Ulloa UC, Pool A, Montiel OM, Arbelaez AL, Cutaia DM. Flora of Nicaragua. Monog. Syst Bot Miss Bot Gard. 2001; 85:740-57.

109. Hussain K, Nisar MF, Majeed A, Nawaz K, Bhatti H. Ethnomedicinal survey for important plants of Jalalpur Jattan district Gujrat, Punjab, Pakistan. Ethnobot Leafl. 2010; 14:807-25.

110. Ashraf A, Sarfraz RA, Rashid MA, Shahid $M$. Antioxidant, antimicrobial, antitumor, and cytotoxic activities of an important medicinal plant (Euphorbia royleana) from Pakistan. J Food Drug Anal. 2014; 23:109-15. 
111. Lansky EP, Paavilainen HM, Pawlus AD, Newman RA. Ficus spp. (fig): Ethnobotany and potential as anticancer and anti inflammatory agents. J Ethnopharmacol. 2008; 119:195-213.

112. Kislev ME, Hartmann A, Bar-Yosef O. Early domesticated fig in the Jordan Valley Science. 2006; 312:1372-4.

113. Wilkinson A. The Garden in ancient Egypt, London. 1998.

114. Doshi GM, Une HD, Shanbhag PP. Rasayans and non-rasayans herbs: Future immunodrug - Targets. Pharmacog Rev. 2013; 7:92-6.

115. Ikram A, Versiani MA, Shamshad S, Ahmed SK, Ali ST, Faizi S. Ixorene, a new dammarane triterpene from the leaves of $I$. coccinea Linn Rec Nat Prod. 2013; 7:302-6.

116. Rahman AU, Taqvi SIH, Versini MA, Ikram A, Ahmed SK. Effect of whole flower and fractions of I.coccinea on cardiovascular system, A preliminary report. J Chem Soc Pak. 2012; 34:758-66.

117. Dickey RD. The genus Jasminum in Florida. Proc Florida State Hortic Soc. 1949; 62:201-4.

118. Espín JC, Soler-Rivas C, Wichers HJ. Characterization of the total free radical scavenger capacity of vegetable oils and oil fractions using 2,2diphenyl- 1-picrylhydrazyl radical. J Agric Food Chem. 2000; 48:648-56.

119. Clark AM, Jurgens TM, Hufford CD. Antimicrobial activity of juglone. Phytotherapy Res. 1990; 4:11-5.

120. Chakraborty A, Brantner AH. Study of alkaloids from Adhatoda vasica Nees on their antiinflammatory activity. Phytother Res. 2001. 15:532-4.

121. Dhankhar S, Kaur R, Ruhil S, Balhara M, Dhankhar S, Chhillar AK. A review on Justicia adhatoda: A potential source of natural medicine. Afr J PI Sci. 2011; 5:620-7.

122. Khalil MY, Moustafa AA, Naguib NY. Growth, phenolic compounds and antioxidant activity of some medicinal plants grown under organic farming condition. World J Agric Sci. 2007; 3:451-7.

123. Ghous T, Aziz N, Mehmood Z, Andleeb S. Comparative study of antioxidant, metal chelating and antiglycation activities of Momordica charantia flesh and pulp fractions. Pak J Pharm Sci; 28:1217-23.

124. Iqbal S, Bhanger MI. Effect of season and production location on antioxidant activity of Moringa oleifera leaves grown in Pakistan. J Food Comp Anal. 2006; 19:544-51.

125. Nair AGR, Subramanian SS. Pigments of the flowers of Moringa pterygosperma. Curr Sci. 1962; 31:155-6.
126. Justesen $U$, Knuthsen $P$. Composition of flavonoids in fresh herbs and calculation of flavonoid intake by use of herbs in traditional Danish dishes. Food Chem. 2001; 73:245-50.

127. Bibi F, Ahmad H, Qureshi RA, Shaheen N, Tabbasum S, Mulk S, et al. Ethno medicinal attributes and antioxidant screening of some selected plant species of Tanawal area, Pakistan. Int J Biosci. 2016; 9:237-54.

128. Khan $H$, Jan $S A$, Javed $M$, Shaheen $R$, Khan $Z$, Ahmad $A$, et al. Nutritional composition, antioxidant and antimicrobial activities of selected wild edible plants. J Food Biochem. 2015; 40:61-70.

129. GRIN Taxonomy Database. USDA, ARS, National Genetic Resources. 2010. https://www.arsgrin.gov/cgi-bin/npgs/html/tax_search.pl

130. Qaiser M, Abid R. Flora of Pakistan: Asteraceae inulaea, plucheaue and Gnaphaleae. Mis. Bot. Pres. Miss. Bot. Gard. St. Louis. Mis. USA. 2003; 210:2935.

131. Kazimierz B. The genus Periploca L. A Monograph. Arboret. Korn. 1966; 11:5-104.

132. Rahman S, Ismail M, Muhammad N, Ali F, Chishti AK, Imran M. Evaluation of the stem bark of Pistacia Integerrima Stew ex Brandis for its antimicrobial and phytotoxic activities. Afr J Pharm Pharmacol. 2011; 5:1170-4.

133. Shinwari ZK, Khan AA, Nakaika T. Medicinal and other useful plants of district Swat Pakistan. Peshawar press, Al-Aziz communications. 2003; 718.

134. Khalid MH, Siddiqui H. Pharmacognostical evaluation and qualitative analysis of Saccharum spontaneum (Linn.) root. Int J Pharm Sci Drug Res. 2011; 3:33841.

135. Zubaida Y, Zabta KS, Mir AK. Phenetic analysis of medicinally important species of the genus Solanum from Pakistan. Pak J Bot. 2010; 42:1827-33.

136. Alvarez M, Rodriguez J, Paniego N, Giulietti A. Solasodine production in transformed organ cultures of Solanum eleagnifolium. Biotech Lett 1994; 16:3936.

137. Rao PS, Navinchandra SR, Jayaveera KN. Medicinial values of Solanum nigrum L. Europ J Exp Biol. 2012; 6:2271-9.

138. Chidrawar VR, Patel KN, Sheth NR, Shiromwar SS, Trivedi P. Antiobesity effect of Stellaria media against drug induced obesity in Swiss albino mice. AYU. 2011; 32:576-84. 
139. Tabassum S. An overview of medicinal importance of Swertia chiraytia. Int J Appl Sci Technol. 2012; 2:298304.

140. Kacker S, Gupta AK, Sharma AK, Lata S, Sharma R. A study on the activity of Swertia chirata and Ocimum Sanctum in animal model of arthritis. J Evol Med Dent Sci. 2013; 2:4058-69.

141. Verma KV, Sarwa KK, Kumar A, Zaman MK. Comparison of hepatoprotective activity of Swertia chirayita and Andrographis paniculata plant of NorthEast India against $\mathrm{CCl}_{4}$ induced hepatotoxic rats. J Pharm Res. 2013; 7:647-53.

142. Singh UP, Singh DP, Maurya S, Maheshwari R, Singh $M$, Dubey RS, et al. Investigation on the phenolics of some spices having pharmacotherapeutic properties. J Herb Pharmacother. 2004; 4:27-42.

143. Sabudak T, Ozturk M, Goren AC, Kolak U, Topcu G. Fatty acids and other lipid composition of five Trifolium species with antioxidant activity. Pharm Biol. 2009; 47:137-41.

144. Upton R. Stinging nettles leaf (Urtica dioica L.): Extraordinary vegetable medicine. J Herb Med. 2013; 3:9-38.
145. Kritikar KR, Basu BD, Nadkarni KM. Indian plants and drugs with their medicinal properties and uses. New Delhi, Asiatic publishing House. 2001.

146. Alam N, Hossain M, Khalil MI, Moniruzzaman M, Sulaiman SA, Gan SH. High catchin concentrations detected in Withiana somniferra (Ashwagandha) by high performance liquid chromatography analysis. BMC Compl Alt Med. 2011; 11:65-70.

147. Sultana B, Anwar F, Asi MR, Chatha SAS. Antioxidant potential of extracts from different agro wastes: Stabilization of corn oil. Grasas Y Aceit. 2008; 59:205-17.

148. Khan A, Farooq U, Ullah F, Iqbal J, Khan AF, Zaib S, et al. Determination of biological activities and total phenolic contents of flowers of Jasminum humile and roots of Dorema aucheri. J Chem Soc Pak. 2014; 36:291-5.

149. Rasool N, Rızwan K, Zubaıri M, Gulzar T, Bukhari IH, Gilani MA, et al. Antioxidant activity of various extracts and organic fractions of Ziziphus jujube. Int J Phytomed. 2011; 3:346-52. 